Natural Hazards and Earth System Sciences (2003) 3: 469-486

(C) European Geosciences Union 2003

Natural Hazards and Earth System Sciences

\title{
The impact of landslides in the Umbria region, central Italy
}

\author{
F. Guzzetti, P. Reichenbach, M. Cardinali, F. Ardizzone, and M. Galli \\ Consiglio Nazionale delle Ricerche, Istituto di Ricerca per la Protezione Idrogeologica, via della Madonna Alta 126, I-06128 \\ Perugia, Italy
}

Received: 8 November 2002 - Revised: 10 February 2003 - Accepted: 26 March 2003

\begin{abstract}
The Umbria Region of Central Italy has a long history of mass movements. Landslides range from fast moving rock falls and debris flows, most abundant in mountain areas, to slow moving complex failures extending up to several hectares in the hilly part of the Region. Despite landslides occurring every year in Umbria, their impact remains largely unknown. We present an estimate of the impact of slope failures in the Umbria region based on the analysis of a catalogue of historical information on landslide events, a recent and detailed regional landslide inventory map, and three event inventories prepared after major landslide triggering events. Emphasis is given to the impact of landslides on the population, the transportation network, and the built-up areas.

Analysis of the available historical information reveals that 1488 landslide events occurred at 1292 sites in Umbria between 1917 and 2001. In the same period 16 people died or were missing and 31 people were injured by slope movements. Roads and railways were damaged by slope failures at 661 sites, and 281 built-up areas suffered landslide damage. Three event inventories showing landslides triggered by high intensity rainfall events in the period 1937-1941, rapid snow melting in January 1997, and earthquakes in September-October 1997, indicate the type, abundance and distribution of damage to the population, the built-up areas and the transportation network caused by typical landslidetriggering events. Analysis of a geomorphological landslide inventory map reveals that in some of the municipalities in the region total landslide area exceeds $25 \%$. Of the more than 45700 landslide areas shown in the geomorphological inventory map, 4115 intersect a road or railway, and 6119 intersect a built-up area. In these areas slope failures can be expected during future landslide triggering events.
\end{abstract}

\section{Introduction}

Due to the lithological, morphological and climatic setting landslides are abundant in Umbria. Mass movements oc-

Correspondence to: F. Guzzetti (f.guzzetti@irpi.cnr.it) cur almost every year in the region in response to prolonged or intense rainfall, rapid snow melting and earthquake shaking. Landslides in Umbria can be very destructive and have caused damage at many sites, including the city of Perugia, and the towns of Allerona, Assisi, Montone, Todi and Orvieto (Felicioni et al., 1994). Figure 1 shows examples of typical landslide damage caused by slope failures in the region. In the 20th century a total of 26 people died or were missing and 31 people were injured by natural slope movements in Umbria.

Landslide mapping and landslide hazard assessments and risk evaluations have been attempted in the Umbria region (Guzzetti and Cardinali, 1989; Antonini et al., 1993; Felicioni et al., 1994; Guzzetti et al., 1999a, b; Cardinali et al., 2002a, b). Despite these efforts, the impact of slope failures in the Region is largely unknown. In this paper we report on the results of an attempt to estimate the impact of landslides in Umbria. Emphasis is given to the estimation of the impact of slope failures on the population, the transportation network, and the built-up areas.

\section{General setting}

The Umbria region extends for $8456 \mathrm{~km}^{2}$ in central Italy (Fig. 2). Elevation ranges from 50 to $2436 \mathrm{~m}$ a.s.l. The landscape is hilly or mountainous, with open valleys and large intra-mountain basins. The Tiber River, a tributary of the Tyrrhenian Sea, drains the area. Climate is Mediterranean, with distinct wet and dry seasons. Rainfall occurs mainly from October to December and from March to May, with cumulative annual values ranging between 500 and $2100 \mathrm{~mm}$. Snowfall occurs every year in the mountains and about every five years at lower elevations.

Four major lithological complexes in Umbria can be further subdivided into seven groups of rock units (Fig. 2). The carbonate complex comprises layered and massive limestone, cherty limestone and marl, pertaining to the UmbriaMarche stratigraphic sequence, Lias to Eocene in age. The 


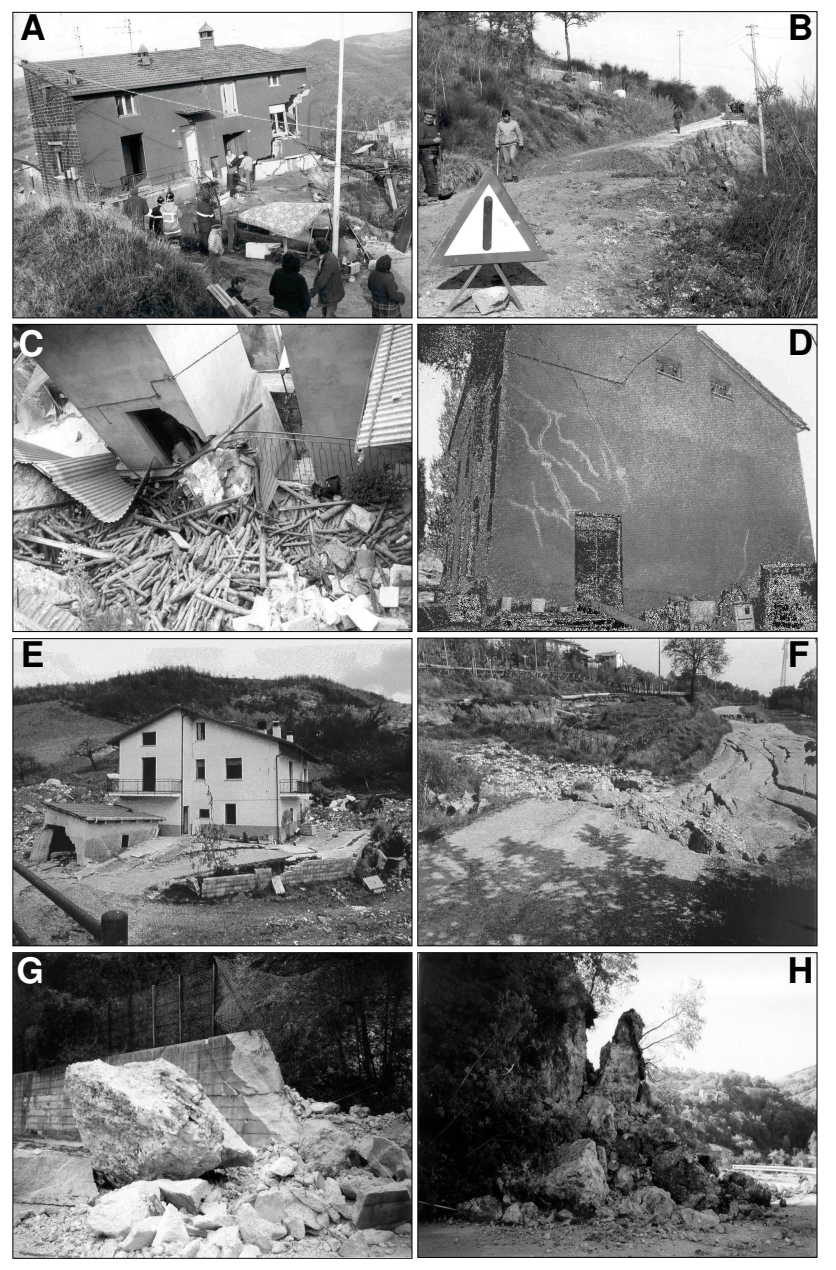

Fig. 1. Typical landslide damage in the Umbria region. (A) House destroyed by a deep-seated slide at Monteverde on December 1982. (B) Road damaged by the Monteverde landslide. (C) Building damaged by a rock fall at Piedipaterno on 15 September 1992. (D) House damaged by a deep-seated landslide triggered by rapid snow melting in January 1997 at Bivio Saragano. (E) House destroyed by the Valderchia landslide of 6 January 1997. (F) Road damaged by a deep-seated slump at San Litardo in January 1997. (G) Damage due to rock falls triggered by the October 1997 earthquake along State Road 320. (H) Rock fall and toppling failure caused by the September-October 1997 earthquakes along a provincial road near Stravignano.

flysch complex contains layered sandstone, marl, shale and clay, Miocene to Oligocene in age, and it can be subdivided into a sandy flysch (Cervarola Fm.) predominant in the western part of the region, a marly flysch (Marnoso Arenacea Fm.) that crops out in the central and northern parts of the region, and chaotic, extremely deformed, clay and marl sedimentary rocks pertaining to the Ligurian sequence and cropping out in the western part of the region. The volcanic complex is limited to the southwestern corner of the region, and it encompasses lava flows, ignimbrites and other pyroclastic deposits that overly marine sedimentary rocks. The postorogenic complex contains marine and lake deposits made up
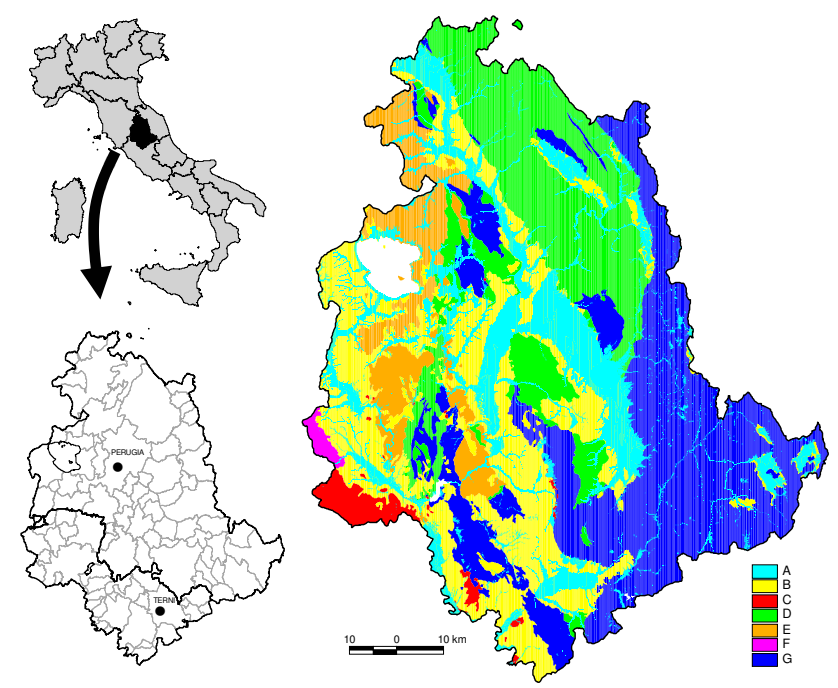

Fig. 2. Umbria Region. Location of the study area and map of the rock units cropping out in Umbria. (A) Recent alluvial deposits, (B) Post-orogenic, marine, lake and continental sediments, (C) Volcanic rocks, (D) Marly flysch (Marnosa Arenacea Fm.), (E) Sandy flysch (Cervarola Fm.), (F) Ligurian sequence, (G) Carbonate complex (Umbria-Marche stratigraphic sequence).

of clay, silty clay, fine and coarse sand, gravel and cobbles. It can be subdivided into: marine, lake and fluvial deposits, Pliocene to Pleistocene in age, and recent alluvial deposits cropping out in the valley bottoms and in the intra-mountain basins (Servizio Geologico d'Italia, 1980; Cardinali et al., 2001).

Geomorphological investigations revealed that landslides cover about eight percent of the entire territory. Landslide abundance and pattern vary within each lithological complex that is characterised by a prevalent geomorphological setting and by typical geotechnical and hydrogeological properties. Failures are largely controlled by the relative position of sedimentary and tectonic discontinuities, by the relative abundance of hard versus weak or soft rocks, and by the presence and attitude of permeable and impermeable layers (Guzzetti et al., 1996).

\section{Background and methods}

The determination of the economic and societal impact of landslides requires the assessment of landslide risk. According to Varnes and the IAEG Commission on Landslides and other Mass Movements on Slopes (1984), landslide risk evaluation aims to determine "the expected degree of loss due to a landslide (specific risk) and the expected number of live lost, people injured, damage to property and disruption of economic activity (total risk)". Quantitative (i.e. probabilistic) and qualitative (i.e. heuristic) approaches are possible (Cruden and Fell, 1997; Fell, 1994; Einstein, 1988; 1997; Kong, 2002). Quantitative landslide risk assessment aims to establish the probability of occurrence of a catastrophic 

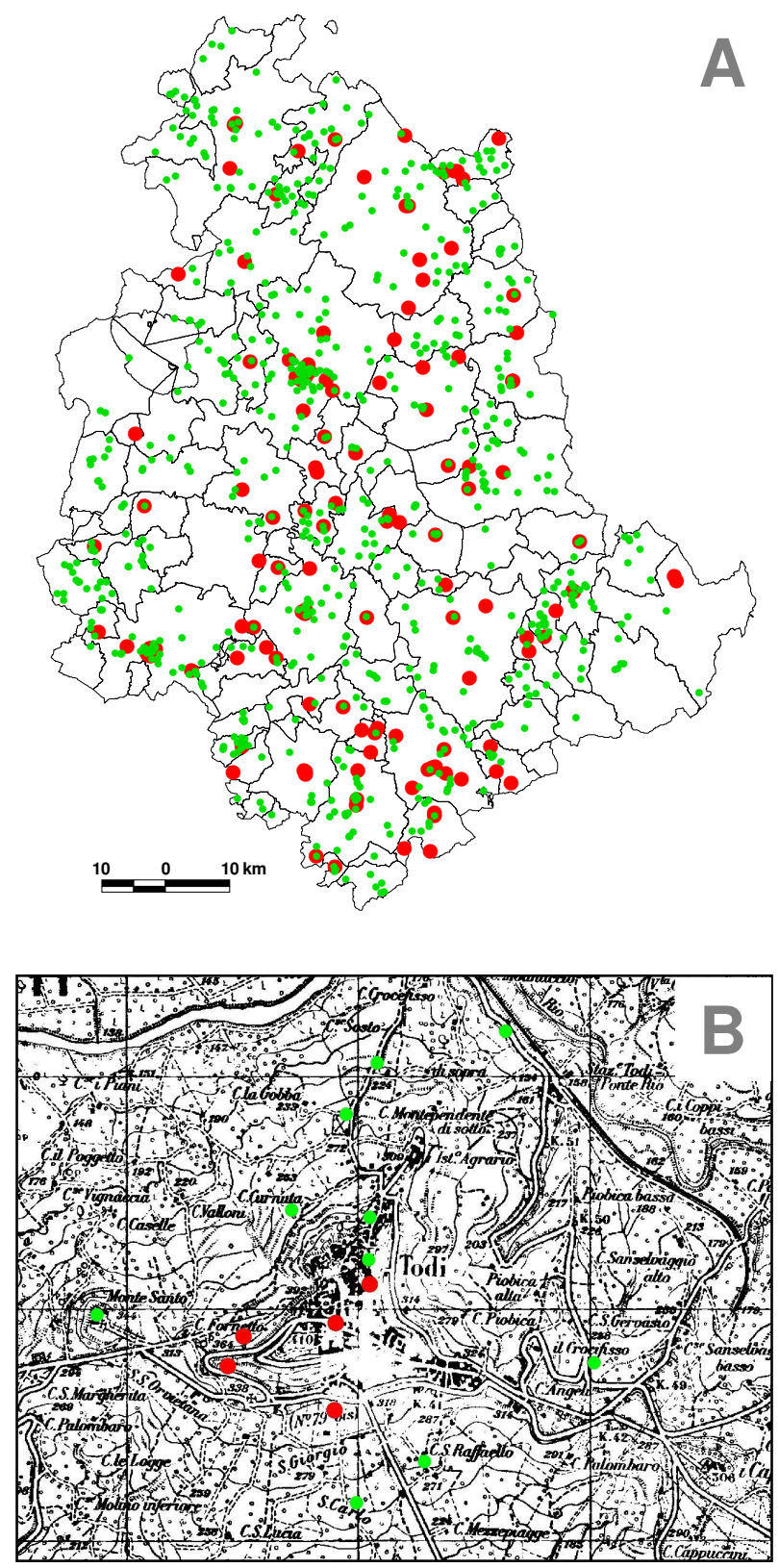

Fig. 3. (A) Map of sites historically affected by landslides in Umbria between 1917 and 2001. (B) Enlargement showing cartographic detail. Legend: green dot $=1$ landslide event; red dot $>1$ landslide event.

event, e.g. the probability of live losses, or the probability of a landslide causing one or more casualties (Fell and Hartford, 1997). Risk of landslide fatalities was determined quantitatively for Canada (Evans, 1997), Italy (Guzzetti, 2000) and Hong Kong (Kong, 2002). When a catalogue of dated landslides is available, the average recurrence interval between the landslides can be determined. Assuming the frequency of slope failures will remain the same for the future, the probability of occurrence of landslides can be determined assuming a Poisson probability model (Crovelli, 2000; Coe et al., 2000). The result is a quantitative estimate of landslide risk.
The completeness and time span of a landslide catalogue affect the reliability of the risk assessments. Unfortunately compiling reliable catalogues of landslides with consequences is difficult, time consuming and expensive (Ibsen and Brunsden, 1996; Glade, 1998; Guzzetti, 2000).

When attempting to evaluate landslide risk for a site or region where slope failures are likely to take various forms or pose various types of threat, the quantitative approach often becomes impracticable. In these areas a qualitative approach can be pursued. This involves designing landslide scenarios. For 79 towns in the Umbria region, Cardinali et al. (2002b) determined qualitative levels of specific landslide risk based on the geomorphological interpretation of several sets of aerial photographs of different ages (a process of multi-temporal landslide mapping), combined with the analysis of historical information on past landslide events.

An alternative to the design of landslide scenarios is the analysis of the impact that slope failures have had, or may have, in a given area. This can be accomplished in two ways. First, where a historical catalogue of landslides and their consequences is available, the sites repeatedly affected by catastrophic events can be determined and the vulnerability of the elements at risk ascertained. Alternatively, where a detailed landslide inventory map and a map of the structures and the infrastructure are available in GIS form, simple geographical operations allow one to determine where landslides may interfere with the elements at risk.

In the following we describe an attempt to determine the impact of slope failures in the Umbria Region using quantitative and qualitative approaches.

\section{Landslide data}

We consider three sources of information on landslides:

- A historical catalogue of landslide events, compiled by searching the archives and by reading several thousands of newspaper articles.

- A geomorphological landslide inventory map, completed through the interpretation of hundreds of medium- and large-scale aerial photographs, aided by field checks.

- Three landslide-event inventory maps, obtained by interpreting aerial photographs taken after a period of prolonged rainfall, a rapid snowmelt, and an earthquake.

\subsection{Historical archive of landslide events}

The historical archive of landslide events was compiled in the framework of a long term, national effort aimed at determining the sites historically affected by landslides and floods in Italy (Guzzetti et al., 1994). For the Umbria region the archive was obtained by searching 79 technical and scientific reports and papers, and by systematically screening two regional newspapers ("La Nazione" and "Il Messaggero") for 
Table 1. Landslide damage in Umbria in the period 1917-2001. Information available for 840 landslide events. Damage is classified as light (i.e. aesthetic or minor damage), severe (i.e. functional or medium damage), and total (i.e. major or structural damage)

\begin{tabular}{|c|c|c|c|c|c|c|c|c|}
\hline & \multicolumn{2}{|c|}{ Light damage } & \multicolumn{2}{|c|}{ Severe damage } & \multicolumn{2}{|c|}{ Total damage } & \multicolumn{2}{|c|}{ Cumulative values } \\
\hline & $\#$ & $\%$ & \# & $\%$ & $\#$ & $\%$ & \# & $\%$ \\
\hline Structures & 66 & 26.5 & 156 & 62.7 & 27 & 10.8 & 249 & 22.4 \\
\hline - Architectural heritage & 5 & 16.7 & 23 & 76.7 & 2 & 6.7 & 30 & 2.7 \\
\hline - Private buildings & 58 & 31.2 & 106 & 57.0 & 22 & 11.8 & 186 & 16.7 \\
\hline - Industrial buildings & 2 & 28.6 & 5 & 71.4 & & 0.0 & 7 & 0.6 \\
\hline - Public buildings & 1 & 3.8 & 22 & 84.6 & 3 & 11.5 & 26 & 2.3 \\
\hline Transportation network & 238 & 34.2 & 428 & 61.6 & 29 & 4.2 & 695 & 62.5 \\
\hline - Highways and freeways & 1 & 33.3 & 1 & 33.3 & 1 & 33.3 & 3 & 0.3 \\
\hline - Other roads & 208 & 32.2 & 410 & 63.6 & 27 & 4.2 & 645 & 58.0 \\
\hline - Railways & 29 & 61.7 & 17 & 36.2 & 1 & 2.1 & 47 & 4.2 \\
\hline Lifelines & 20 & 17.2 & 74 & 63.8 & 22 & 19.0 & 116 & 10.4 \\
\hline Others & 4 & 7.7 & 43 & 82.7 & 5 & 9.6 & 52 & 4.7 \\
\hline Total & 328 & 29.5 & 701 & 63.0 & 83 & 7.5 & 1112 & \\
\hline
\end{tabular}

the period 1917-1991. A third regional newspaper ("Corriere dell'Umbria") was used for the period 1991-1998, and was substituted by "Il Messaggero" for the period 19992001.

Due to the technique used to compile the archive, landslide events listed in the historical catalogue concentrate mostly in urban areas and along or around the transportation network and lifelines. We have considered all the events reported in the catalogue as "landslides with consequences", i.e. landslides that have caused damage to people, buildings, the infrastructure or land-use. Figure 3A shows the geographical distribution of these sites.

For the Umbria region the catalogue lists 1488 landslide events that have occurred at 1292 sites. Landslide sites were mapped (as points) on 1:25000 scale topographic maps (Fig. 3B) based on the name of the places damaged by the slope failures reported in the newspaper articles or in the reports. Where detailed cartographic information was available, mostly from the technical reports, this information was used to locate more precisely the historical landslide events. The complete date of occurrence (i.e. year, month, day or period of days) is known for 804 landslide events, allowing for the determination of the recurrence of landslide events. There are 114 sites $(10.4 \%)$ that have been affected by landslides more than once. The archive also contains information on the vulnerability to slope failures (Table 1).

\subsection{Geomorphological landslide inventory map}

In 1989 Guzzetti and Cardinali published the first systematic landslide inventory map for the Umbria region. The map was published at 1:100 000 scale and was obtained through a reconnaissance analysis of black \& white aerial photographs taken in 1954-1955 at approximately 1:33000 scale. The reconnaissance inventory was partially revised by Antonini et al. (1993) for the Apennines mountain chain. More recently, we completed a new and more detailed geomorphological landslide inventory map for the entire Umbria region (AA.VV., 2002; Cardinali et al., 2001). The new inventory was obtained by re-interpreting the 1:33000 aerial photographs flown in 1954-1955, and by analysing large scale $(\sim 1: 13000)$, colour aerial photographs taken in 1977. Due to time constrains, the latter photographs were interpreted only where lake and continental deposits Plio-Pleistocene in age crop out. Landslides were mapped at 1:10000 scale on topographic maps prepared by the Umbria Regional Government (CTR series).

The geomorphological inventory map contains all the landslides that left discernable features in the aerial photographs used to complete the inventory. We estimate that the inventory is complete for landslides larger than about 2 ha. Landslides of smaller size may have not been recognized consistently, or may have been removed by erosion, or concealed by younger slope failures, or subdued by growth of vegetation or human activity, mostly ploughing. Landslides were classified according to their type of movement (Varnes, 1978), the estimated depth, relative age, degree of activity, and mapping certainty (AA.VV., 2002).

The geomorphological inventory map portrays 47414 landslides, including 1563 debris flows and 131 rock falls shown as points. The map also shows: 760 rock slopes identified as possible sources of rock falls, for a total area of $14.6 \mathrm{~km}^{2} ; 553$ talus zones where rock fall deposits are abundant, for a total area of $12.1 \mathrm{~km}^{2}$; and debris deposits, alluvial cones and alluvial fans, for a total area of $365.9 \mathrm{~km}^{2}$. Landslides extend in size from few tens of square meters to $2.19 \mathrm{~km}^{2}$, and cover a total area of $712.64 \mathrm{~km}^{2}, 8.4 \%$ of the 
Table 2. Comparison of landslide inventories. (A) Rainfall induced landslides in the period 1937-1941 (1), and snowmelt induced landslides in January 1997 (2a, entire study area; 2b, area where aerial photographs were available). (B) September-October 1997 earthquake induced landslides. (C) Geomorphological landslide inventory map. $\mathrm{N}_{\mathrm{LT}}$, total number of landslides; $\mathrm{A}_{\mathrm{LT}}$, total landslide area; $\mathrm{A}_{\mathrm{Lmin}}, \mathrm{A}_{\mathrm{Lmax}}, \overline{\mathrm{A}}_{\mathrm{L}}$, minimum, maximum, average landslide area; $V_{L T}, V_{L m i n}, V_{L m a x}, V_{L}$, similar values for landslide volume; $d_{L}$, landslide density

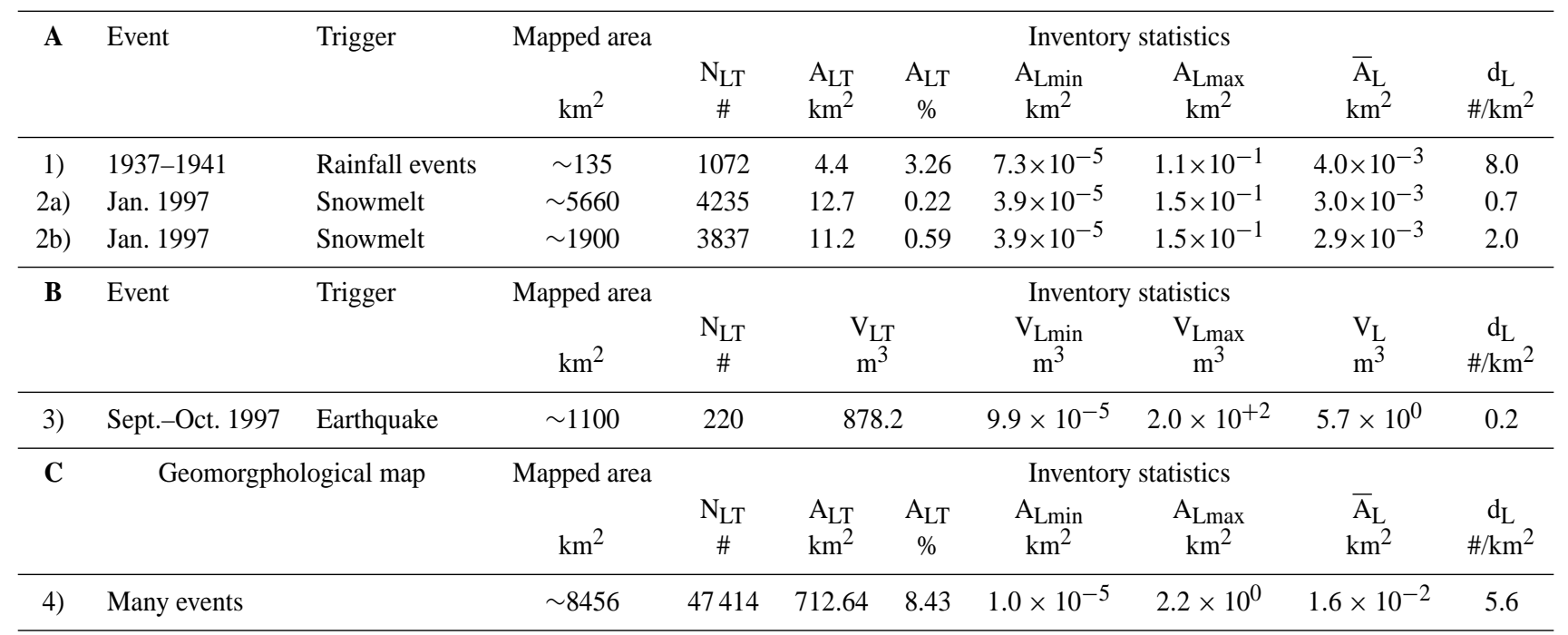

entire territory (Table 2). The percentage increases to $10.0 \%$ if large valley bottoms and intra-mountain basins where landslides do not occur are excluded from the analysis. The most abundant landslides shown in the map have an area of about $1100 \mathrm{~m}^{2}$. Figure 4A shows the distribution of the mapped landslides. Landslides shown in the inventory are mostly slides, slide-earth flows and complex or compound slope movements. These types of movements represent the vast majority of the landslides recognized in the region. In addition, debris flows (5.3\%) were recognized in the Apennines mountain chain, where limestone crops out. Rock falls and topples are present in all lithological complexes, and are most common where hard rocks, mostly limestone, sandstone, and volcanic rocks, crop out along steep slopes (Guzzetti et al., 1996; AA.VV., 2002). The age of most of the landslides in the Umbria region is unknown, but the oldest and largest failures are believed to be Holocene in age (Guzzetti et al., 1996).

Landslides are not distributed evenly in the region (Table 3 and Fig. 4B). Failures are most abundant in the flysch complex, where $50.7 \%$ of all landslides were identified. Within this rock complex, the area where marly flysch crops out exhibits the largest number of landslides (32.7\%). In the post-orogenic sediments complex and the carbonate complex landslide abundance is similar, $27.8 \%$ and $20.7 \%$, respectively. Landslides are less abundant in the volcanic complex $(0.8 \%)$. Slope failures initiate in the underlying marine clays and affect only the edge of the volcanic rock hard cap (Guzzetti et al., 1996). Figure 4C shows the relationship between landslide areas and terrain gradient, computed from a DTM with a ground resolution of $25 \times 25 \mathrm{~m}$. In the Umbria region landslides are most abundant where slope is between
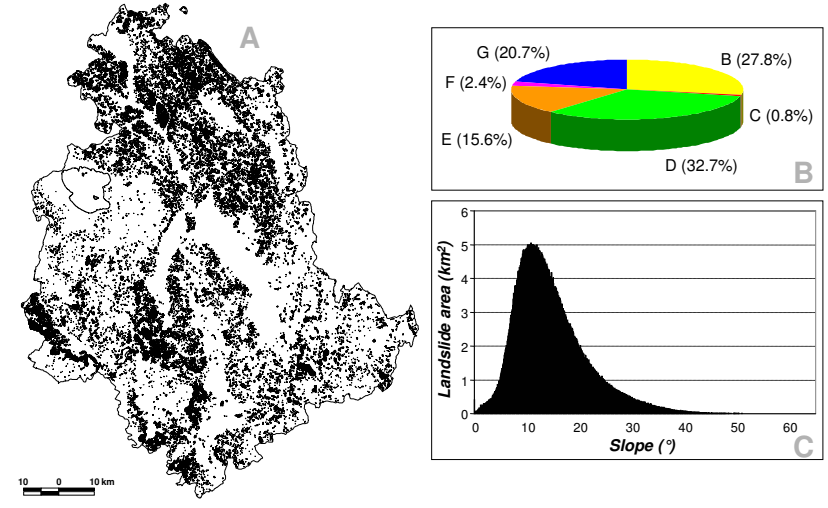

Fig. 4. Geomorphological landslide inventory map. A) Geographical distribution of landslides. (B) Abundance of landslide areas in the rock units cropping out in the Region (for colour legend see Fig. 1). (C) Landslide abundance and terrain gradient.

8 and $20^{\circ}$. The abundance of landslides in the various slope categories varies depending on the lithological complex and the landslide type.

\subsection{Event inventories}

Event inventory maps record the location and the type of landslides caused by a specific trigger, i.e. a rainfall event, rapid snow melting, or earthquake. Three event inventories were made by us. They were prepared for the 1937-1941 rainfall period (Fig. 5A), the January 1997 snowmelt event (Fig. 5B), and the September-October 1997 earthquake sequence (Fig. 5C). Landslides were mapped on the same topographic maps used for the geomorphological inventory map, 
Table 3. Landslide abundance in the lithological complexes and the groups of rock units cropping out in the Umbria region (see Figs. 1 and $3 \mathrm{~B})$. Last column is the percentage of landslide area $\left(\mathrm{A}_{\mathrm{L}}\right)$ with respect to the total landslide area $\left(\mathrm{A}_{\mathrm{LT}}=712.64 \mathrm{~km}^{2}\right)$

\begin{tabular}{|c|c|c|c|c|c|c|c|}
\hline & \multirow[t]{2}{*}{ Lithological complex } & \multirow[t]{2}{*}{ Group of rock units } & \multicolumn{2}{|c|}{ Rock unit area } & \multicolumn{2}{|c|}{ Landslide area $\left(\mathrm{A}_{\mathrm{L}}\right)$} & \multirow{2}{*}{$\begin{array}{c}\mathrm{A}_{\mathrm{L}} / \mathrm{A}_{\mathrm{LT}} \\
\%\end{array}$} \\
\hline & & & $\mathrm{km}^{2}$ & $\%$ & $\mathrm{~km}^{2}$ & $\%$ & \\
\hline & \multicolumn{2}{|l|}{ Post-orogenic complex } & 3242.1 & 38.34 & 198.5 & 6.12 & 27.8 \\
\hline A & & Alluvial deposits & 1394.8 & 16.49 & - & - & - \\
\hline $\mathrm{B}$ & & Lake, continental and marine deposits & 1847.3 & 21.85 & 198.5 & 6.12 & 27.8 \\
\hline $\mathrm{C}$ & & Volcanic complex & 151.3 & 1.79 & 5.4 & 3.60 & 0.8 \\
\hline & \multicolumn{2}{|l|}{ Flysch complex } & 2445.6 & 28.92 & 360.8 & 14.75 & 50.7 \\
\hline $\mathrm{D}$ & & Marly flysch (Marnoso Arenacea Fm.) & 1729.5 & 20.45 & 232.4 & 13.44 & 32.7 \\
\hline $\mathrm{E}$ & & Sandy flysch (Cervarola Fm.) & 676.8 & 8.00 & 111.1 & 16.42 & 15.6 \\
\hline $\mathrm{F}$ & & Ligurian sequence & 39.3 & 0.46 & 17.3 & 43.95 & 2.4 \\
\hline G & & Carbonate complex Umbria-Marche stratigraphic sequence & 2617.0 & 30.95 & 147.4 & 5.63 & 20.7 \\
\hline & \multicolumn{2}{|l|}{ Umbria Region } & 8465.0 & & 712.6 & 8.38 & \\
\hline
\end{tabular}

i.e. CTR topographic maps at 1:10000 scale. Table 2 summarizes the characteristics of the three event inventories.

The period between September 1937 and May 1941 was particularly wet in Umbria. Figure 6 shows the mean annual precipitation (MAP) that we computed for five rain gauges in the period 1921-1960. Between 1937 and 1941 the regional MAP was $1,186 \mathrm{~mm}$, this is $25.4 \%$ higher that the average MAP for the 40-years period between 1921 and 1960, and $29.5 \%$ higher than the average MAP for the period 19212000. Particularly severe rainfall events occurred on 6-7 October 1937, on 16-18 December 1937, on 14-15 May 1939, on 25 October 1940, and on 20 February 1941. During these events rainfall intensity locally exceeded $200 \mathrm{~mm}$ in one day (211 mm at Ficulle on 7 October 1937, and $210 \mathrm{~mm}$ at Casalina on 25 October 1940). Some of the events affected limited areas. Other events involved the entire region. The event of 16-18 December 1937 produced the largest historical flood in the Tiber River basin (Reichenbach et al., 1998) and caused extensive inundations along the Tiber River and many of its tributaries. In the period 1937-1941 the historical catalogue (Guzzetti et al., 1994) lists 78 sites affected by floods and 13 sites affected by landslides. Reasons for the discrepancy between the large number of sites affected by inundations and the comparably much smaller number of sites where landslides were reported is unknown (Reichenbach et al., 1998). Landslides listed in the catalogue caused damage to railroads (4 sites), roads (4 sites), built-up areas (6 sites) and other infrastructures (2 sites).

Aerial photographs were taken in central Umbria in June 1941 by military pilots during reconnaissance flights. The black \& white photographs were taken both vertically (at an approximate scale of 1:18000) and obliquely. Through the interpretation of 60 aerial photographs, covering an area of about $13 \mathrm{~km}^{2}$ between Deruta and Todi, we prepared a detailed landslide inventory map at 1:10000 scale for landslides triggered between September 1937 and May 1941 (Fig. 5A). The inventory contains 1072 landslides, for a total landslide area of $4.38 \mathrm{~km}^{2}, 3.26 \%$ of the study area (Ta- ble 2). The average landslide density was 8 landslides $/ \mathrm{km}^{2}$, but locally landslide density was much higher, exceeding 50 landslides $/ \mathrm{km}^{2}$. Landslides were mostly shallow soil slips $(65.0 \%)$, flows $(23.7 \%)$, and earth flows $(9.8 \%)$. Deep seated failures $(1.5 \%)$ were translational and rotational slides, and complex slump-earth flows.

In January 1997 the rapid melting of a thick snow cover caused abundant landslides in the Umbria region (Cardinali et al., 2000). Field investigations were started immediately after the event to identify and map the landslides, and to identify the areas where slope failures were most abundant. In these areas aerial photographs at approximately 1:20000 scale were taken three months after the event, covering an area of $1896 \mathrm{~km}^{2}$. Interpretation of the aerial photographs taken after the event allowed us to prepare a detailed landslide inventory map at 1:10000 scale (Fig. 5B). The inventory shows 4235 landslides, for a total landslide area of $12.7 \mathrm{~km}^{2}$ (Table 2). This corresponds to $0.15 \%$ of the Umbria region $\left(8456 \mathrm{~km}^{2}\right)$ and to $0.22 \%$ of the investigated area $\left(5664 \mathrm{~km}^{2}\right)$. In the area where aerial photographs were available we mapped 3837 landslides, covering $11.20 \mathrm{~km}^{2}, 0.59 \%$ of the study area. Damage to buildings and to the infrastructure was reported at 39 sites (Fig. 1D-F). Damage to the agriculture was also severe. At several places wheat fields were severely affected by landslides. At many of these sites wheat was killed by the landslide and therefore not harvested.

On 26 September 1997 the Umbria-Marche area of Central Italy was shaken by two severe earthquakes of 5.6 and 5.8 local magnitude. On 14 October 1997 the same area experienced another earthquake of similar magnitude $\left(\mathbf{M}_{\mathrm{L}}=5.5\right)$. Following the main shocks field surveys were performed to map landslides triggered by the earthquakes, and to determine the main landslide types (Antonini et al., 2002). Information collected at 220 sites (Fig. 5C) revealed that landslides were mostly rock falls, minor rockslides and topples that accounted for $93 \%$ of all the reported mass-movements. The other landslides were equally distributed between debris falls or debris slides, and complex slides. New fractures were 


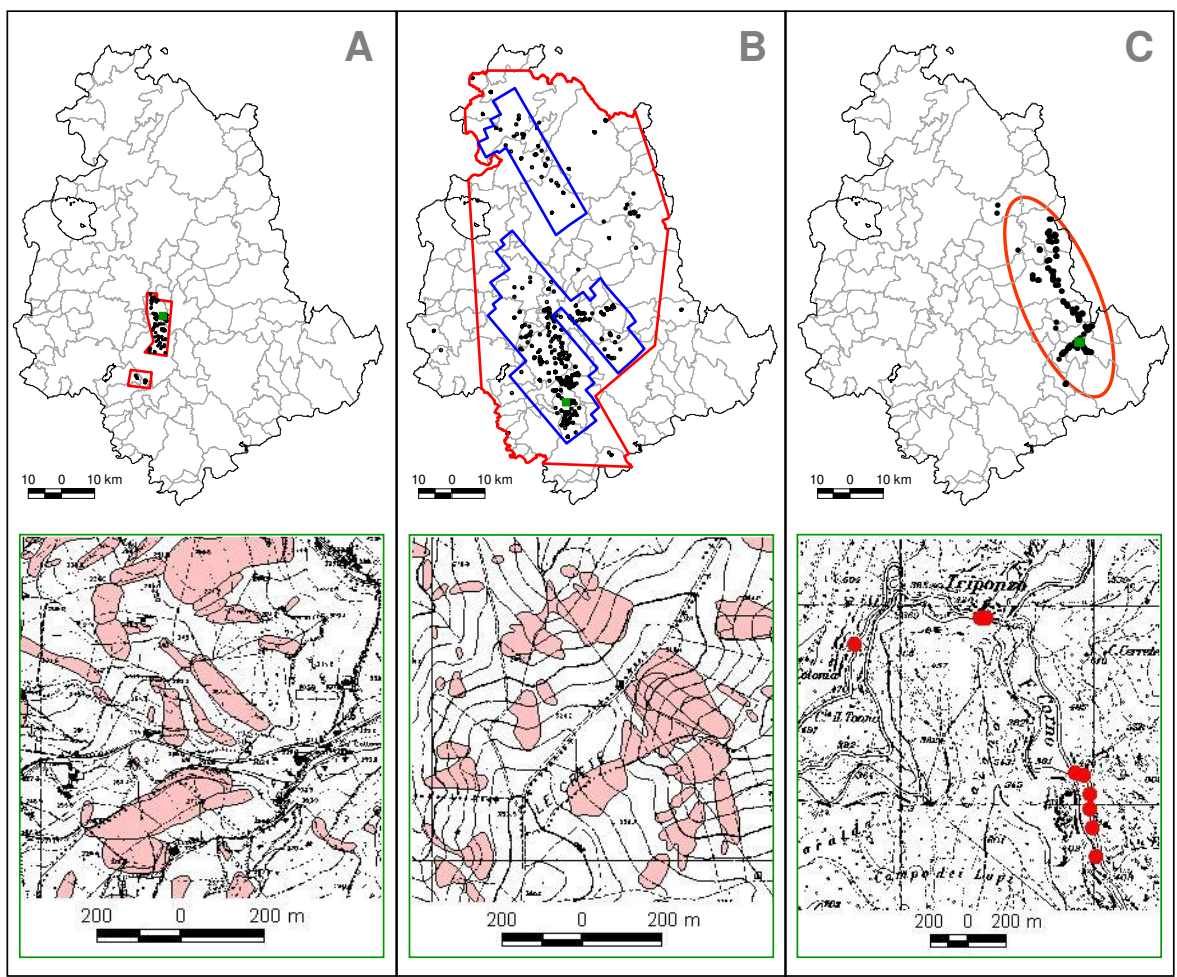

Fig. 5. Landslide event inventories. Red lines show extent of study areas. (A) Landslides triggered by rainfall events in 1937-1941. (B) Landslides triggered by rapid snowmelt in January 1997 (Cardinali et al., 2000). Blue line shows extent of the area for which aerial photographs where available. (C) Landslides triggered by the September-October 1997 earthquake sequence (Antonini et al., 2002). Lower maps are enlargements of portions of the upper maps. The approximate location of the enlarged maps is shown by green squares on the upper maps. Original maps at 1:10000 scale.

mapped in pre-existing landslide deposits, but no major landslide was reactivated to the point of catastrophic failure. The distribution of rock falls fitted the observed macro-seismic intensity pattern. About $50 \%$ of all reported failures occurred within $8 \mathrm{~km}$ from the epicentral area (between Colfiorito and Sellano, cf. Antonini et al., 2002), and the maximum observed distance of a landslide from one of the epicentres was $25 \mathrm{~km}$. Slope failures caused damage mostly to the transportation network (Fig. 1G-H). Two state roads (SS 320 and SS 209) connecting Terni, to the south, with Visso, Norcia and Cascia, to the north and north-east, were damaged at several places by numerous rock falls ranging from small cobles to rock slides $130 \mathrm{~m}^{3}$ in volume. Casualties due to landslides were not reported, but at least one car was damaged by a rock fall.

\section{Information on the vulnerable elements}

In the Umbria region landslides have caused damage to people, private houses and public buildings, industrial and business facilities, transportation and lifeline networks, the agriculture and forests. Damage caused by slope failures can be direct or indirect, and it can be light (aesthetic, minor), severe (functional, major), or total. The latter where life is lost or a structure or infrastructure is destroyed.
To evaluate the impact of landslides in the region, three sources of information were available to us:

- A digital map of the transportation network, prepared by the Regional Government Planning Office by digitizing the roads and railways from 1:25000 topographic maps updated for the purpose in 1983 (Fig. 7A). The data set was locally completed using 1:100 000 scale topographic maps. Roads are classified as highways, freeways, state roads, provincial roads, municipality roads, and other minor roads. The total extent of the transportation network in the digital map is $5564 \mathrm{~km}$ (comprising $523 \mathrm{~km}$ of railway, $278 \mathrm{~km}$ of highway and freeway, and $4763 \mathrm{~km}$ of other roads), corresponding to a density of about $1.3 \mathrm{~km}$ of road or railway every $\mathrm{km}^{2}$. The Regional Government estimates that the total extent of the transportation network exceeds $12000 \mathrm{~km}$ in Umbria (http://www.umbriaterritorio.org/ umbria/Relazione/principale_rel.html). Thus, the digital map portrays only about $46.4 \%$ of the transportation network in the Region. Inspection of the map reveals that all the main roads and railways (i.e. highways, freeways and most of the state roads) are shown in the map, which in places underestimates the extent of the municipality roads and of the other minor roads. 

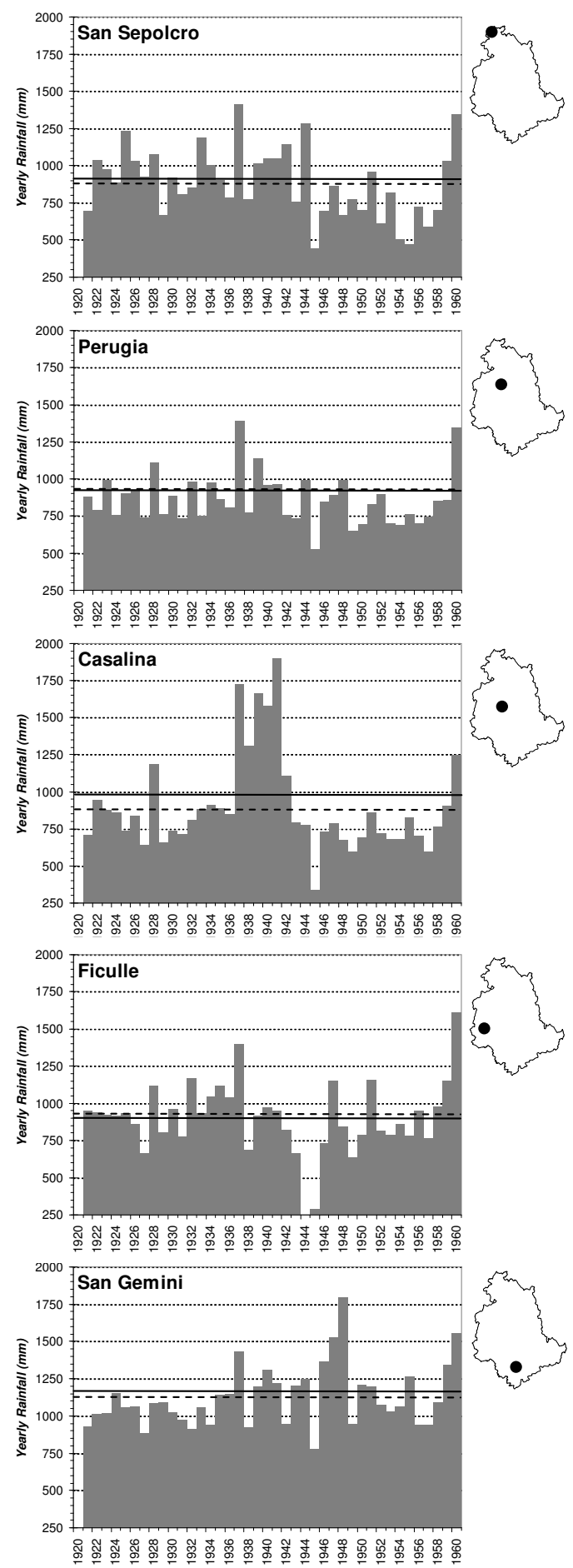

Fig. 6. Mean annual precipitation (MAP) for five rain gauges in the period 1921-1960. Data from Servizio Idrografico (1955a, 1955b, 1955-1961). Maps show location of the rain gauges. Thick line, average MAP for the 30-years period; dashed line, average MAP for the 80-years period between 1921 and 2000.

- A map of the extent of the urban and built-up areas, prepared by the Regional Government Planning Office by digitizing the outline of the built-up areas (i.e. cities,

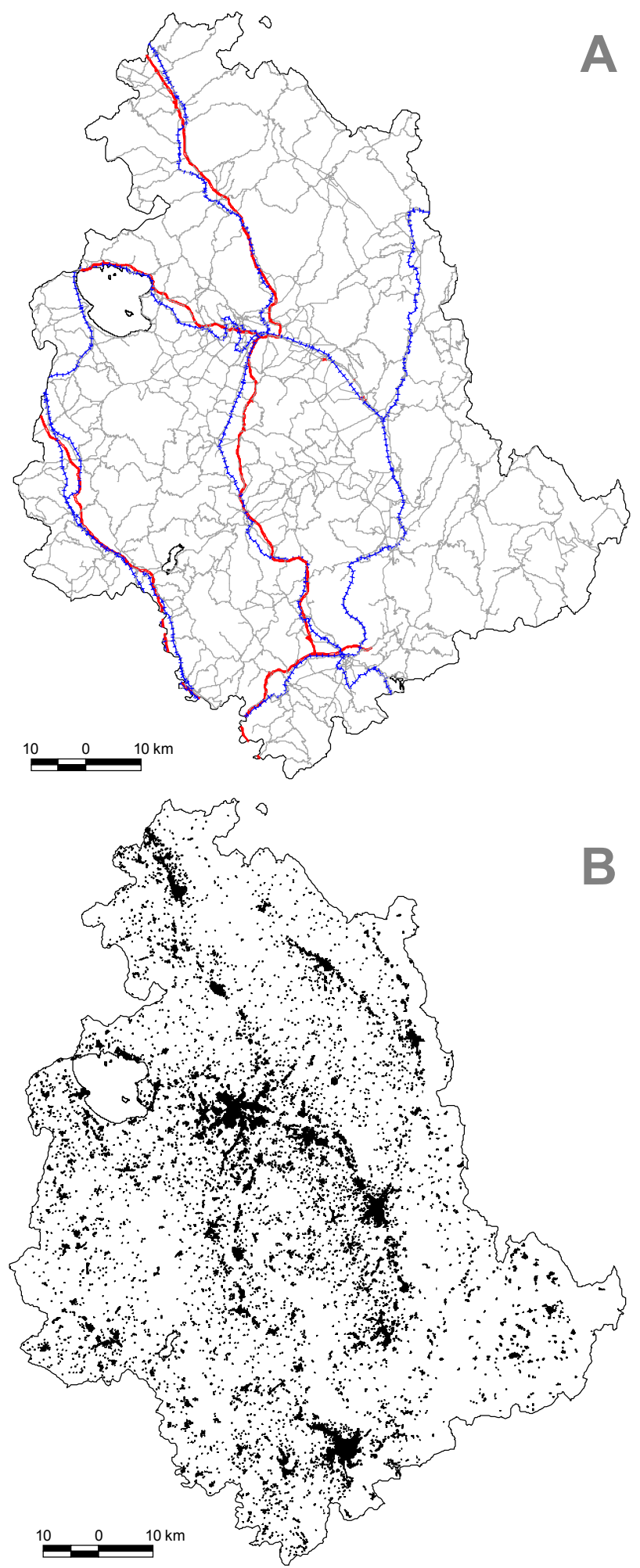

Fig. 7. (A) Map of the transportation network. Legend: red line, highways and freeways (4 lanes); grey line, all other roads (2 lanes); blue hachured line, railways. (B) Map of the built-up areas.

towns, villages, dwellings) from 1:25000 scale topographic maps (Fig. 7B). The digital map shows 30244 


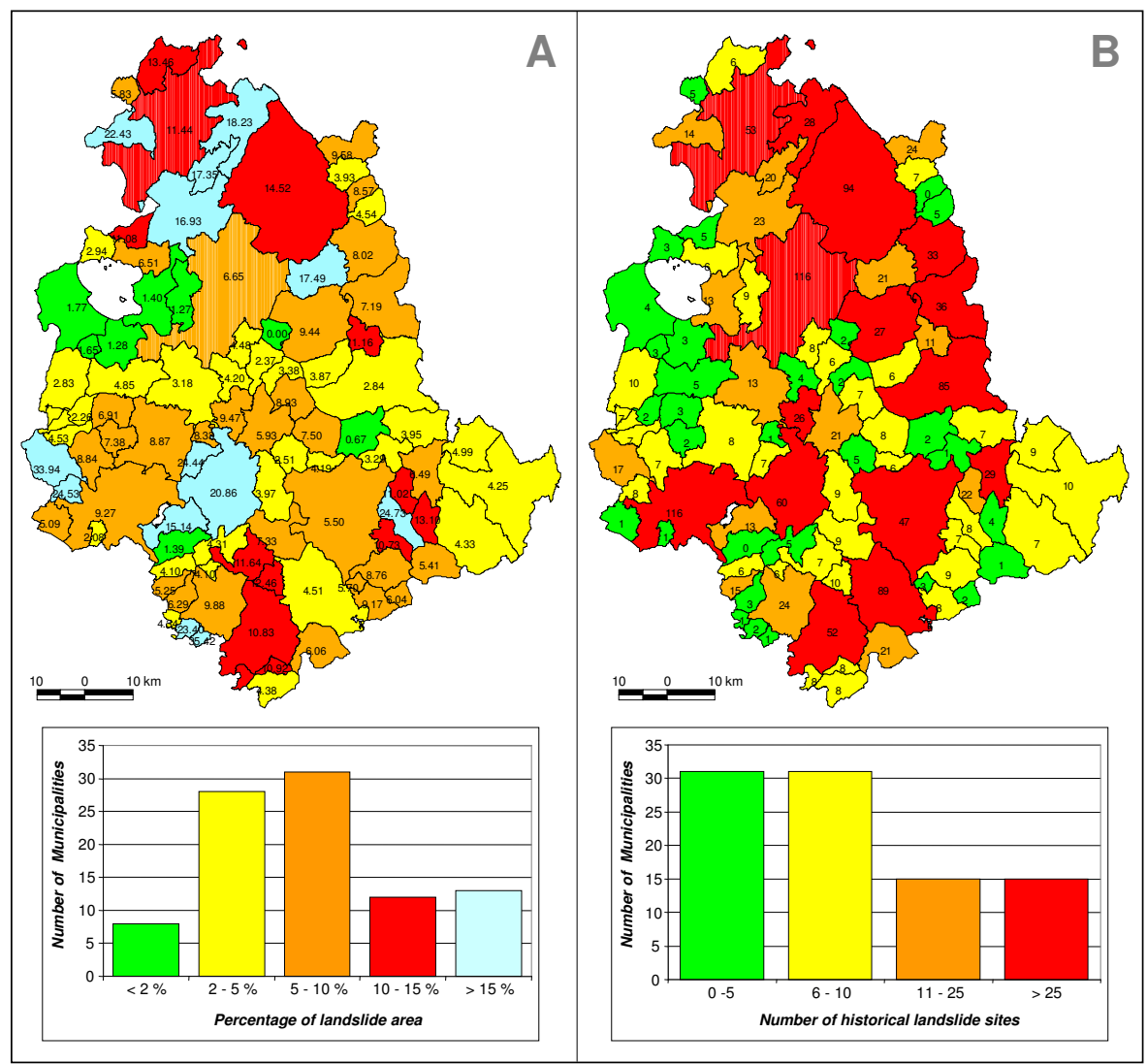

Fig. 8. (A) Percentage of landslide areas in the 92 Municipality of the Umbria region. Histogram shows number of Municipalities in five classes of the percentage of landslide area. (B) Number of historical landslide sites in each Municipality. Histogram shows abundance of Municipalities in four classes of number of historical landslide sites.

areas, for a total built-up area of $382 \mathrm{~km}^{2}, 4.52 \%$ of the Umbria territory. This information was last updated in 1977, and may not be accurate in the areas where new developments have been undertaken after that date.

- For the Perugia Municipality, a map showing the population density in 701 census zones. The extent of the census zones varies from $269 \mathrm{~m}^{2}$ in the urban area to $15.8 \mathrm{~km}^{2}$ in the rural area.

The quality and resolution of the cartographic information on the location and the types of vulnerable elements is not the same as that of the information shown in the landslide inventory maps. Landslide inventory maps were prepared at 1:10000 scale and digitized at the same scale. When compiling the inventories care was taken in locating the landslides with respect to possible elements at risk (e.g. buildings, roads, etc.). The available information on the elements at risk was obtained at 1:25000 scale and digitization was not particularly accurate. This introduces errors and uncertainties in the analysis of the impact that landslides may have on the transportation network and the built-up areas.

\section{Analysis and discussion}

The available information on landslides allows for different analyses of the impact that slope failures had, and may have in the Umbria region. Since the research focuses on determining the impact of landslides, the analysis will be carried out from the point of view of the elements at risk. In this section we compare the distribution of landslide areas obtained from the geomorphological inventory map with the distribution of landslide events obtained from the historical archive, and we determine the impact of mass-movements on the population, the built-up areas, and the transportation network.

\subsection{Regional distribution of landslide phenomena}

The geomorphological landslide inventory map and the historical catalogue of landslide events provide different and complementary pictures of the distribution and the density of landslide phenomena in the Umbria region. The geomorphological inventory map (Fig. 4A and Table 2C) indicates that total landslide area in the region is $712.64 \mathrm{~km}^{2}(8.4 \%)$, of which $519.12 \mathrm{~km}^{2}$ is in the Perugia province $(8.2 \%)$ and $192.52 \mathrm{~km}^{2}$ in the Terni province $(9.1 \%)$. This is a minimum estimate because an unknown number of landslides were removed by erosion, human activities and growth of vegeta- 
tion, and small landslides may have not been recognized in the aerial photographs or in the field. Figure 8A shows the percentage of landslide area in the 92 Municipalities of the region. The percentage of landslide area varies from $0 \%$ (Bastia) to more than 30\% (Allerona, 33.9; Penna in Teverina, $35.4 \%)$.

The historical catalogue of landslide events covers the period 1917-2001 and reports information on 1292 landslide sites, affected by a total of 1488 landslide events. This is equivalent to 1.5 landslide sites per $10 \mathrm{~km}^{2}$ in 85 years. Landslide events were reported in 90 of the 92 Municipalities in the region $(97.8 \%)$. Figure $8 \mathrm{~B}$ shows the number of sites affected by landslides in each Municipality. The number of landslide sites ranges from 0 (Sigillo, Montecchio), where no historical information was reported, to 116 , for the Perugia Municipality. This is equivalent to an average of 1.4 damaging landslide events per year. Due to the technique used to collect the information, the historical archive is incomplete. Figure 9 shows the abundance of historical landslide events for different time intervals. In this figure, the slope of the cumulative curve reveals various levels of completeness of the catalogue.

The historical catalogue allows for estimating the recurrence of landslide events. Considering the period 19172001 , most of the landslide sites (1158, i.e. $89.6 \%)$ were affected only once, $78(7.6 \%)$ were affected 2 times, and 36 (2.8\%) were affected three to six times in 85 years (Fig. 3A). This information allows for computing the average recurrence of landslides in the 92 Municipalities in the Umbria region. Average recurrence can be computed by dividing the total number of landslide events in each Municipality by the time span of the catalogue (i.e. 84 years). Assuming that landslide recurrence will remain the same for the future and adopting a Poisson probability model, we can determine for different time intervals the exceedance probability of having one or more damaging landslide in each Municipality (Coe et al., 2000). Figure 10A and Table 4 show that, for a 5-years period, only 5 municipalities $(5.4 \%)$ have a 0.90 or larger probability of experiencing at least one damaging landslide, and 17 municipalities $(18.5 \%)$ have a 0.50 or larger probability of experiencing at least one damaging slope failure. These figures increase to $11(12.0 \%)$ and $40(43.5 \%)$ municipalities for a 10-years period (Fig. 10B) and to 25 (27.2\%) and 68 (73.9\%) municipalities for a 25 -years period (Fig. 10C), respectively (Table 4). Despite the known and clear limitations of adopting a Poisson probability model to predict the occurrence of future landslide events based on the past landslide recurrence (Coe et al., 2000; Crovelli, 2000), Fig. 10 provides a quantitative estimate of landslide risk in Umbria.

The three event inventories, prepared for events (or group of the events in the case of the 1937-1941 period) that occurred in Umbria between 1937 and 2001, provide useful information on the type, extent, persistence and abundance of failures caused by landslide triggering events. Comparison in a GIS of the spatial distribution of landslides triggered by the 1937-1941 rainfall period and the January 1997 snowmelt event, with the geographical distribution of the pre-existing

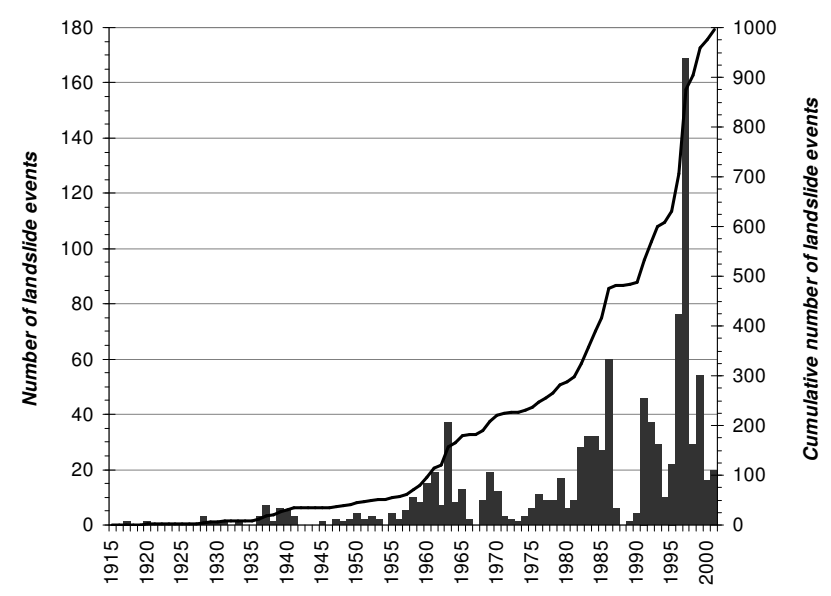

Fig. 9. Historical landslide events in Umbria for the period 19172001. Histogram shows yearly number of landslide events. Thick line shows cumulative number of landslide events.

landslides shown in the geomorphological inventory map allows for estimating the spatial persistence of landslides. Approximately $89 \%$ of all the rainfall induced landslides triggered in the period 1937-1941 were located inside or within $150 \mathrm{~m}$ from a pre-existing landslide (Fig. 11A). Similarly, about $75 \%$ of the snowmelt induced landslides fell inside pre-existing landslide deposits, i.e. they were reactivations, or they were located within $150 \mathrm{~m}$ of an existing landslide (Fig. 10B). This is an important information for the assessment of landslide hazards in the Umbria region (Guzzetti et al., 1999b; Cardinali et al., 2002a) because it provides the rationale for attempting to evaluate where landslides may cause damage in the future based on where landslides have occurred in the past using accurate landslide inventory maps.

Analysis of the frequency-size statistics of the triggered landslides helps evaluating landslide hazards and risk. Figure $12 \mathrm{~A}$ shows the probability densities of landslide areas for the 1937-1941 period (blue triangles) and the January 1997 snowmelt event (red squares). The distributions exhibit the typical trend of frequency-area distributions of landslides (Stark and Hovius, 2001; Guzzetti et al., 2002). The frequency of slope failures increases with the landslide area up to a maximum value, where landslides are most abundant, and then it decays along a power law. The slope of the power law is about -2.4 . The "rollover" for the two datasets occurs at about $A L=4.5 \times 10^{-4}$ to $6.0 \times 10^{-4} \mathrm{~km}^{2}$ (i.e. $\sim 20 \times 20$ to $\sim 25 \times 25 \mathrm{~m}^{2}$ ). This is not a significantly large difference considering the complexity of the landslide phenomena, and the errors and uncertainty associated with the identification and mapping of landslides from the aerial photographs or in the field. Figure 12B shows the probability density of landslide volumes for the rock falls, topples and minor rock slides triggered by the September-October 1997 earthquake sequence. Similarly to other rock-fall data sets (Hungr et al., 1999; Dussage-Peisser et al., 2002), the distribution obeys a power law, with exponent $\sim-1.0$. This suggests scale invariance for the volume of rock falls triggered by seismic 


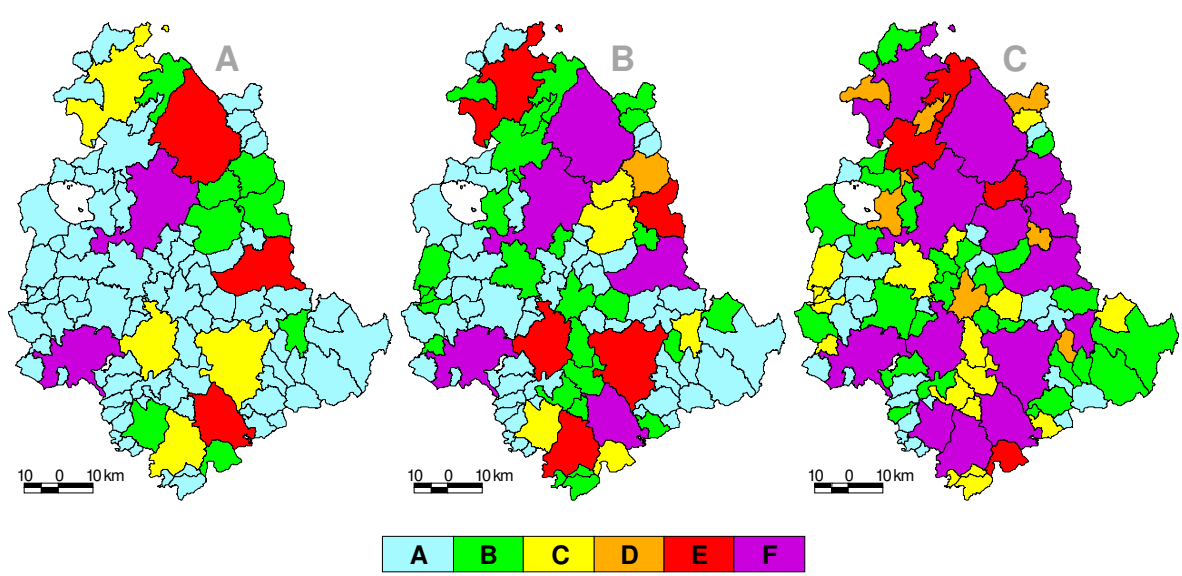

Fig. 10. Maps showing annual exceedance probabilities of damaging landslide events in the 92 Municipalities of the Umbria region. Exceedance probability computed based on historical information for the 85-years period between 1917 and 2001. (A) 5-years forecast; (B) 10 -years forecast; (C) 25-years forecast. Colours indicate annual probability values in 6 classes: A, blue, [0.0-0.50]; B, green, (0.50-0.80]; C, yellow, (0.80-0.90]; D, orange, (0.90-0.95]; E, red, (0.95-0.99]; F, purple, (0.99-1.00]. Therefore, the areas of Umbria coloured purple have the highest probability for landslides each year.

Table 4. Number and percentage (in parenthesis) of municipalities in the Umbria region that exceed the given probability of experiencing one or more damaging landslide. Values for different time intervals, from 5 to 50 years. Based on a historical record spanning the 85 -years period between 1917 and 2001

\begin{tabular}{cccccc}
\hline Exceedance probability & $5 \mathrm{yrs}$ & $10 \mathrm{yrs}$ & $20 \mathrm{yrs}$ & $25 \mathrm{yrs}$ & $50 \mathrm{yrs}$ \\
\hline$>0.99$ & $2(2.2 \%)$ & $5(5.4 \%)$ & $11(12.0 \%)$ & $14(15.2 \%)$ & $25(27.2 \%)$ \\
$>0.95$ & $5(5.4 \%)$ & $10(10.9 \%)$ & $16(17.4 \%)$ & $18(19.6 \%)$ & $40(43.5 \%)$ \\
$>0.90$ & $5(5.4 \%)$ & $11(12.0 \%)$ & $19(20.7 \%)$ & $25(27.2 \%)$ & $58(63.0 \%)$ \\
$>0.80$ & $9(9.8 \%)$ & $16(17.4 \%)$ & $30(32.6 \%)$ & $40(43.5 \%)$ & $68(73.9 \%)$ \\
$>0.50$ & $17(18.5)$ & $40(43.5 \%)$ & $68(73.9 \%)$ & $68(73.9 \%)$ & $76(82.6 \%)$ \\
\hline
\end{tabular}

shaking in Umbria across at least five orders of magnitude. The probability densities of landslide area and volume obtained for the Umbria region can help determine landslide hazards. They can be used to forecast the abundance of failures of any given size caused by landslide triggering events, i.e. a rainfall, snowmelt or earthquake. This may prove important information for preparing quantitative regional landslide scenarios.

\subsection{Landslide impact on the population}

The historical archive contains 65 information on landslide events with human consequences. Analysis of the catalogue indicates that 21 people died, 2 persons are missing, and 40 people were injured by slope failures, in a total of 29 landslide events with human consequences. Seventeen casualties (8 deaths and 9 inured people) were related to human activities, i.e. accidents in the workplace, excavations and open pit mining. Limiting the analysis to the natural landslides, between 1917 and 2002 landslide disasters in Umbria resulted in 47 casualties, comprising 14 deaths, 2 missing persons, and 31 injured people. This is equivalent to an average of about 0.55 deaths, missing persons or injured people per year. Natural landslide disasters with human consequences were 17 , equivalent to an incident with deaths, missing persons or injured people every 5 years, or an annual frequency of 0.2. The largest landslide disaster in the region occurred on 10 May 1939 at Stifone, when six people were killed by a landslide along the railway connecting Terni to Orte. On 19 January 1963, 14 people were injured when a postal train derailed because of three landslides between the stations of Attigliano and Alviano. The historical catalogue lists 34 landslide events for which a total of 897 homeless or evacuated people are reported. This figure is most probably underestimated, because for some of the events the catalogue reports information on houses that were destroyed or severely damaged without providing information on the number of homeless or the evacuated people. For other events the catalogue lists the number of families that were evacuated but not the number of people involved.

A national investigation on landslide risk to people indicates that, in the 20th century, at least 7799 casualties, comprising 5831 deaths, 108 missing persons and 1860 injured people were reported in Italy. This represents an average of 59.4 deaths or missing persons each year (Guzzetti, 2000). If compared to these values, landslide risk to people in Um- 


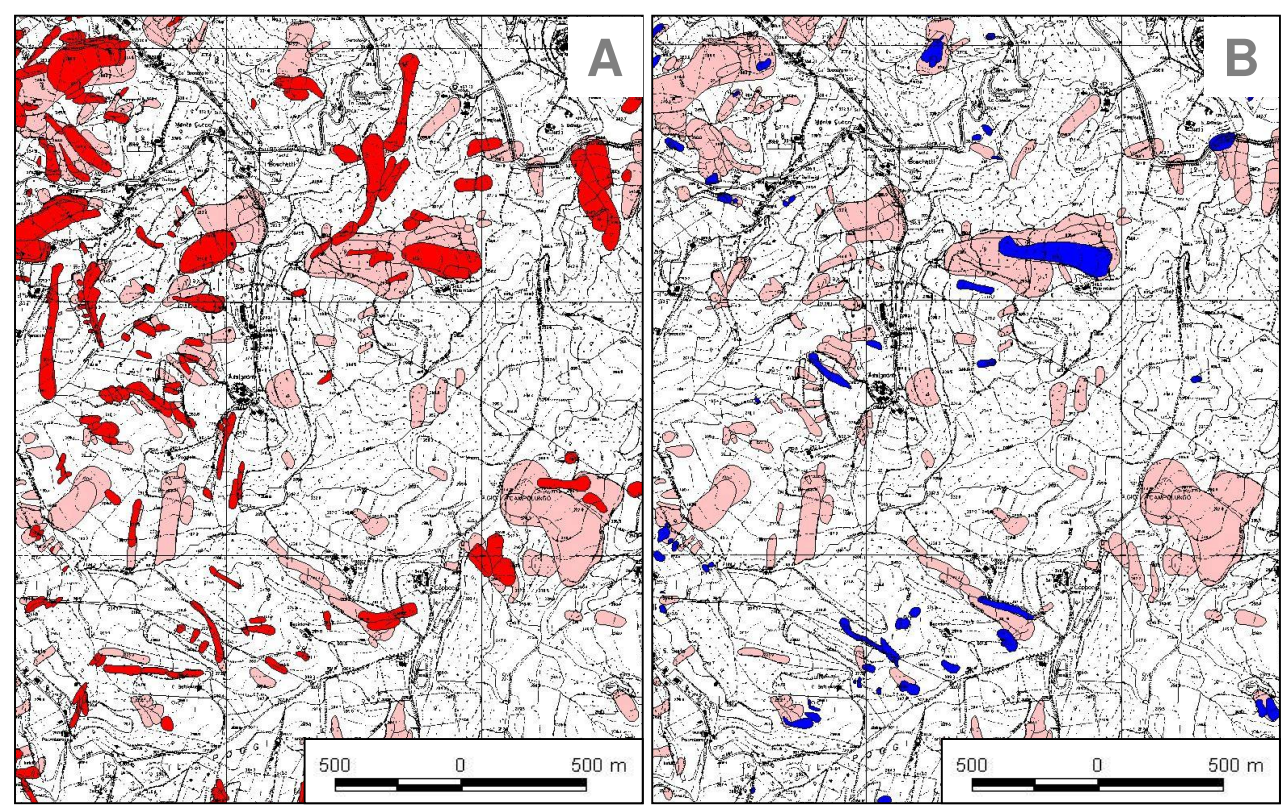

Fig. 11. Spatial persistence of event triggered landslides. (A) Landslides triggered in the period 1937-1941 by rainfall events. (B) Landslides triggered by rapid snowmelt in January 1997. Legend: pink, pre-existing landslides; red, 1937-1941 landslides; blue, January 1997 landslides.

bria is low. This is a consequence of the predominant type of failures causing damage in the region. Damaging slope failures are mostly slides, slide-earth flows and complex or compound movements that commonly travel short distances and move at slow to moderate velocity, allowing for the people to escape when a landslide occurs. As an example, in the early morning of 6 January 1997 a complex landslide involving $1 \times 10^{6} \mathrm{~m}^{3}$ of rock detached from a steep slope above Valderchia, NE of Gubbio (Fig. 1E) (Cencetti et al., 1998). The landslide moved at an estimated velocity of some meter per hour. People in two houses in the path of the landslide heard the walls cracking but were able to escape from the windows. The two houses were rapidly destroyed but no one was killed or injured.

For the Perugia Municipality, the second largest in the region $\left(449.92 \mathrm{~km}^{2}\right)$ and the one with the largest population (157 092 people, in 2001) and the largest population density (349 inhabitants $/ \mathrm{km}^{2}$ ), we have determined the number and location of people potentially subject to landslide risk. In the Municipality the geomorphological inventory shows 2042 landslides, for a total landslide area of $29.80 \mathrm{~km}^{2}, 6.6 \%$ of the entire territory. Active landslides where 187, 9.2\% of all slope failures, and cover $0.56 \mathrm{~km}^{2}, 0.12 \%$ of the territory.

Within a GIS we computed the percentage of landslide area in the 701 census zones in which the Municipality is subdivided (Fig. 12A). The percentage ranges from $0 \%$, in landslide-free areas, to $100 \%$ where an entire census zone falls in a landslide area. Total landslide area is larger in the rural areas, and the percentage of landslide area in each census zone is larger in the urban area. The latter is the result of the small size of census zones in the urban area. Knowing the population of each census zone, we estimated the number of people potentially subject to landslide risk (Fig. 12B). The analysis indicates that in the Perugia Municipality about 9100 people (5.8\% of the population) live in a landslide area, or in the vicinity of a landslide. In at least nine census zone the number of inhabitants subject to landslide risk exceeds 200 people. These sites should be carefully investigated.

What was accomplished is only a first-order estimate of the spatial distribution of landslide risk to people in the Perugia Municipality. The analysis does not take into consideration the exact location of the landslides or the population in the census zones. For simplicity, the analysis was performed considering only the extent of the landslides shown in the geomorphological inventory map for the Perugia Municipality. Possible enlargements of a landslide due to its movement or to reactivations were not considered. Debris flows and rock falls are not shown in the inventory map. Hence, the risk associated with these types of landslide is not considered. Site specific methods aimed at determining the specific landslide risk may be used to overcome these limitations (Cardinali et al., 2002b).

\subsection{Landslide impact on the built-up areas and the trans- portation network}

The historical archive lists information on 281 sites where buildings and other structures were damaged by landslides, and 661 sites where roads and railways were damaged by slope failures (Fig. 1). In the archive damage is classified as light, where damage was aesthetic, severe, where the functionality of the building or the transportation line was compromised, and total where a building was destroyed or a road 

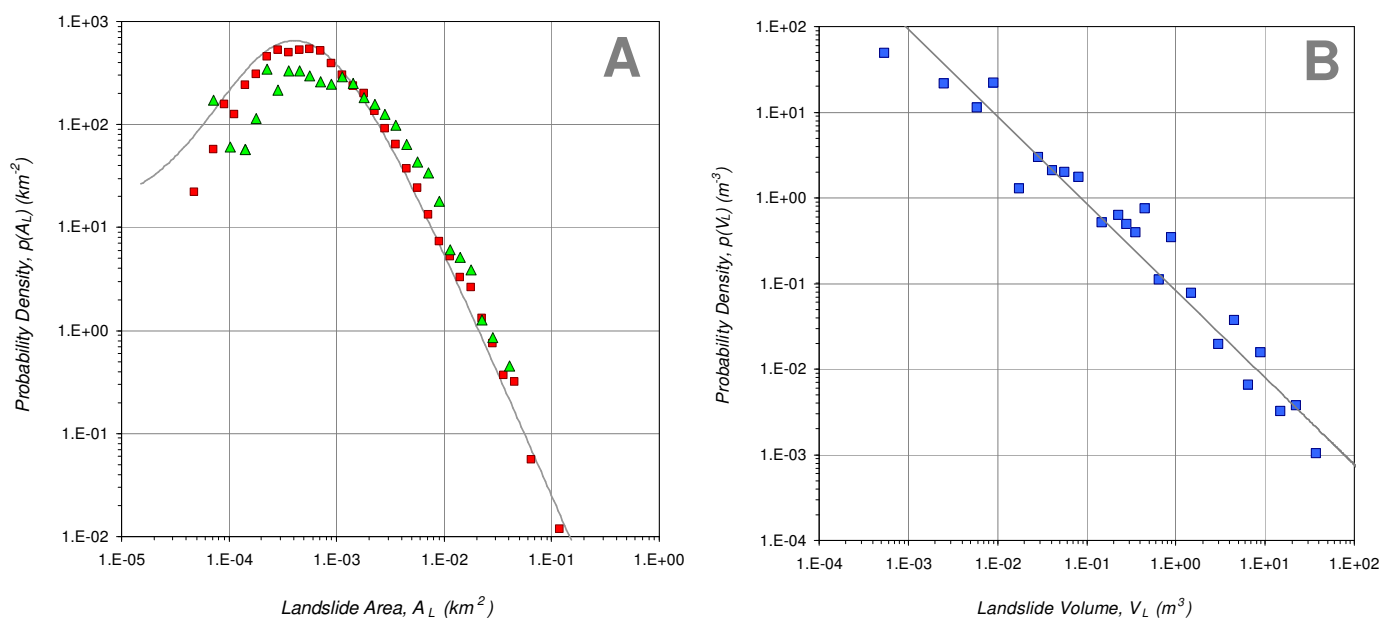

Fig. 12. Frequency size statistics of landslides. (A) Probability density of landslide area for the January 1997 snowmelt event (red squares) and for the 1937-41 rainfall period (blue triangles). Grey line is an inverse-gamma distribution. (B) Probability density of landslide volume triggered by the September-October 1997 earthquake sequence. Grey line is a power law fit with exponent $\sim-1.0$.

Table 5. Buffers used in the GIS analysis of the relationships between landslides, built-up areas and the transportation network. Buffer A defines the extent of the built-up area or the transportation network. Buffer B considers the area in the vicinity of the built-up area or the transportation network

\begin{tabular}{llcc}
\hline Type of element at risk & & $\begin{array}{c}\text { Buffer A } \\
(\mathrm{m})\end{array}$ & $\begin{array}{c}\text { Buffer B } \\
(\mathrm{m})\end{array}$ \\
\hline Highways, Freeways & (4 lanes roads) & 50 & 150 \\
All other roads & (2 lanes roads) & 25 & 80 \\
Railways & (all railways) & 20 & 50 \\
Built-up areas & (houses, buildings, structures) & 0 & 50 \\
\hline
\end{tabular}

or railway was interrupted. Along the transportation network about $34.2 \%$ of the damage was classified as light, $61.6 \%$ as severe and $4.2 \%$ as total damage. For the built-up areas, $26.5 \%$ of the damage was classified as light, $62.7 \%$ as severe, and $10.8 \%$ as total damage (Table 1).

Valuable information on the impact of slope failures on the built-up areas and the transportation network can be obtained analysing the three event inventories. The prolonged earthquake sequence of September-October 1997 caused the largest impact to the transportation network. Rock falls, topples and minor rock slides were mapped at 220 sites along approximately $600 \mathrm{~km}$ of roads. These failures correspond to a density of 2.7 damaging landslides every $\mathrm{km}$. Along the Nera River and the Corno River valleys landslide density was locally much higher. Two main Regional Roads (i.e. SS 320 and SS 209) running at the bottom of the valleys were interrupted at several sites and remained closed for weeks after the earthquakes, while remedial works were completed (Fig. 1G). The road interruptions caused severe transportation problems for the local population, and made it harder for the earthquake post-event relief efforts. At least 15 million Euro were spent by the Department of Civil Protection, the Regional Government, and the National Road Company (ANAS) for repairing the damage and for installing new defensive measures, including several hundreds of meters of rock fall elastic barriers and new artificial tunnels.

Landslides triggered by the January 1997 snowmelt event caused damage mostly to the transportation network and to a few houses, some of which had to be abandoned (Fig. 1D-F). By intersecting in a GIS the map of the transportation network with the event landslide inventory map, we identified 115 sites where landslides triggered by rapid snowmelt interfered (i.e. intersected) with the road and railroad network. Sites damaged by landslides are found one every $56 \mathrm{~km}$ of highways, every $32 \mathrm{~km}$ of roads, and every $47 \mathrm{~km}$ of railways. An additional 112 sites where landslides were in the immediate vicinity of the transportation network were identified by drawing a buffer zone around each road or railway (Table 5). Considering the buffer zone, the frequency of slope failures increase to one every $13 \mathrm{~km}$ of highways, $16 \mathrm{~km}$ of roads and $37 \mathrm{~km}$ of railways. In the area where the aerial photographs were available, we identified 158 sites where landslides intersected (73) or were close to (85) roads and railways. Damage to the transportation network was gen- 
Table 6. Landslide impact in Umbria. (1) Landslides triggered in 1937-1941. (2) Landslides triggered in January 1997. (3) Geomorphological landslide inventory map. Event inventories (1) and (2): $\mathrm{D}_{\mathrm{M}}$, average distance (in $\mathrm{km}$ ) between landslides along the transportation network; $\mathrm{N}_{\mathrm{L}}$, percentage of landslides that interfered with the transportation network or the built-up areas. Geomorphological inventory map (3): $\mathrm{D}_{\mathrm{E}}$, expected distance (in $\mathrm{km}$ ) between landslides along the transportation network; $\mathrm{N}_{\mathrm{L}}$, percentage of landslides that interfere with the transportation network or the built-up areas. Values computed considering only the extent of the structure or infrastructure (buffer A), and considering the vicinities of the structure or infrastructure (buffer B), are shown

\begin{tabular}{|c|c|c|c|c|c|c|}
\hline Data set & \multicolumn{2}{|c|}{ (1) 1937-1941 period } & \multicolumn{2}{|c|}{ (2) January 1997} & \multicolumn{2}{|c|}{ (3) Geomorphological map } \\
\hline Trigger & \multicolumn{2}{|c|}{ Rainfall events } & \multicolumn{2}{|c|}{ Rapid snowmelt } & \multicolumn{2}{|c|}{ Numerous } \\
\hline Study area $\left(\mathrm{km}^{2}\right)$ & \multicolumn{2}{|c|}{135} & \multicolumn{2}{|c|}{5664} & \multicolumn{2}{|c|}{8456} \\
\hline Landslides (\#) & \multicolumn{2}{|c|}{1072} & \multicolumn{2}{|c|}{4235} & \multicolumn{2}{|c|}{45720} \\
\hline Landslide area $\left(\mathrm{km}^{2}\right)$ & \multicolumn{2}{|c|}{4.38} & \multicolumn{2}{|c|}{12.65} & \multicolumn{2}{|c|}{712.64} \\
\hline Landslide area $(\%)$ & \multicolumn{2}{|c|}{3.24} & \multicolumn{2}{|c|}{0.22} & \multicolumn{2}{|c|}{8.43} \\
\hline & $\begin{array}{c}\mathrm{D}_{\mathrm{M}} \\
\mathrm{km}\end{array}$ & $\begin{array}{c}\mathrm{N}_{\mathrm{L}} \\
\%\end{array}$ & $\begin{array}{l}\mathrm{D}_{\mathrm{M}} \\
\mathrm{km}\end{array}$ & $\begin{array}{c}\mathrm{N}_{\mathrm{L}} \\
\%\end{array}$ & $\begin{array}{l}\mathrm{D}_{\mathrm{E}} \\
\mathrm{km}\end{array}$ & $\begin{array}{c}\mathrm{N}_{\mathrm{E}} \\
\%\end{array}$ \\
\hline Highway and freeway (buffer A) & - & - & 56.0 & 0.09 & 2.3 & 0.27 \\
\hline Highway and freeway (buffer B) & - & - & 13.0 & 0.40 & 1.1 & 0.56 \\
\hline All other roads (buffer A) & 4.9 & 2.15 & 32.3 & 2.43 & 1.2 & 8.38 \\
\hline All other roads (buffer B) & 2.3 & 4.57 & 16.3 & 4.72 & 0.9 & 12.12 \\
\hline Railway (buffer A) & - & - & 46.6 & 0.19 & 3.3 & 0.35 \\
\hline Railway (buffer B) & - & - & 37.1 & 0.24 & 2.5 & 0.47 \\
\hline Built-up area (buffer A) & & 6.72 & & 2.88 & & 13.38 \\
\hline Built-up area (buffer B) & & 18.84 & & 15.44 & & 33.48 \\
\hline
\end{tabular}

erally localized. The section of the roads affected by slope failures extended from a few tens to a few hundred meters. The exact amount of money spent repairing the damage along the transportation network is not available to us, but an estimate of the Regional Government suggests that it exceeded 10 million Euro.

Landslides triggered by rainfall events in the period 19371941 probably caused damage to built-up areas, roads and railways. Unfortunately, very little information is available in the historical catalogue that in this period lists only 13 sites where landslide damage is reported. Intersection in a GIS of the map showing the transportation network with the event landslide inventory map (where available, i.e. in a $135 \mathrm{~km}^{2}$ area between Deruta and Todi, cf. Fig. 5A) indicates that landslides have directly interfered with roads of various categories at 27 sites. This is an average of one damaging landslide every $5 \mathrm{~km}$ of roads. At other 26 sites landslides were identified in the immediate vicinity of the transportation network. If the latter sites are considered, the frequency of landslides increases to one every $2 \mathrm{~km}$ along the roads.

A comparison of the effects of the three landslide events on the transportation network can be attempted. The largest number of sites with damage was reported as a result of earthquake induced landslides, mostly because of the types of the seismically-induced failures (i.e. rock falls, topples, and minor rock slides) and the location of the transportation network in the area affected by the earthquakes. Rock falls can be abundant even in areas of limited extent, and they can be very dangerous to people and destructive to structures even for small volumes (less than $1 \mathrm{~m}^{3}$ ). In the mountain area where seismic shaking was most severe in 1997, roads most affected by the rock falls were located at or near the valley bottom.

Landslides triggered by the rapid snowmelt in 1997 and by rainfall events in the period 1937-1941 were similar, and comprised shallow soil slips, slumps and slump-earth flows, and deep-seated slides, slide earth-flows and complex movements. These landslide types move slowly and with generally limited displacements. This type of movement explains why roads were damaged at several places, but were totally interrupted at only a few sites. It may also explain why landslides did not cause casualties. Despite the fact that the abundance of landslides and the average landslide density for the two events were different, the percentage of landslides that interfered with the transportation network was similar, $2.7 \%$ for the 1937-1941 rainfall events and 2.5\% for the January 1997 snowmelt event (Table 6).

The geomorphological landslide inventory map is a good cartographic data set to ascertain where landslides may impact the transportation network and built-up areas in the Umbria region. To accomplish this we have intersected in a GIS the geomorphological landslide inventory map with the maps of the transportation network and of the built-up areas. To account for the possible mapping errors and the lack of geo- 


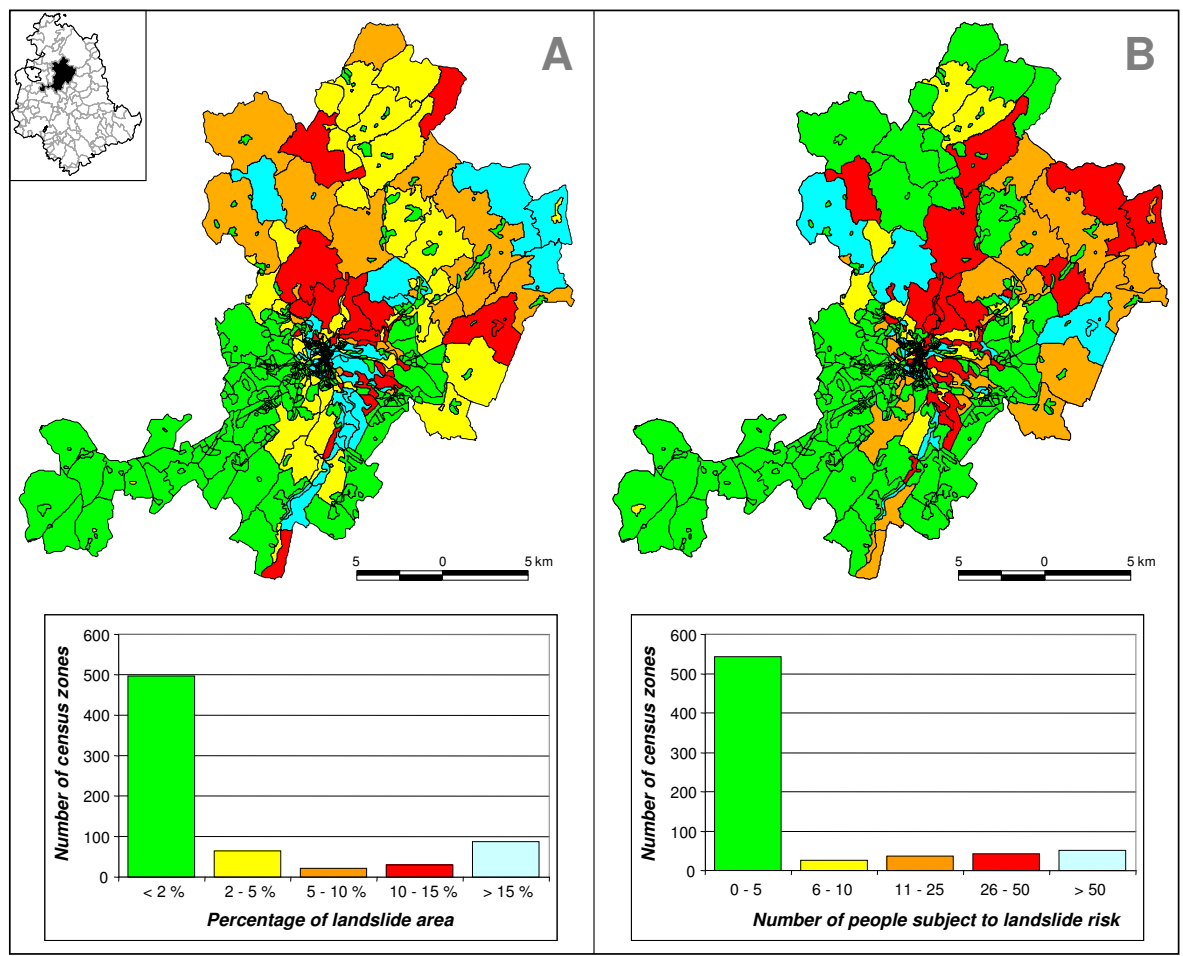

Fig. 13. Perugia Municipality. (A) Map of 701 census zones. Colours show percentage of landslide area in each census zone. Histogram shows abundance of census zones in five classes of the percentage of landslide area. (B) Map showing number of people potentially subject to landslide risk. Histogram shows abundance of census in five classes zones of the number of people subject to landslide risk.

graphical precision in the maps of the transportation network and of the built-up areas, we computed a buffer zone around each road, railway, or built-up area. The size of the buffer was selected depending on the type of the vulnerable element (Table 5).

The GIS analysis identifies 4115 sites where landslides shown in the geomorphological inventory map intersect, i.e. may interfere, with the transportation network (Fig. 14A), and 6119 sites where landslides intersect with the built-up areas (Fig. 14B). The figures were obtained considering the largest buffer zones of Table 5. At these localities damage due to landslides can be expected, particularly during major landslide triggering events (e.g. prolonged rainfall, rapid snowmelt).

Given the available information, about $9.0 \%$ of all the landslides shown in the geomorphological inventory map may cause a direct damage to roads or railways. A frequency of landslide damage can be expected every $2.3 \mathrm{~km}$ along the highways and freeways, every $1.2 \mathrm{~km}$ along the roads, and every $3.3 \mathrm{~km}$ along the railways (Table 6). If roads and railways in the flat valleys and in the large intra-mountain basins are excluded from the analysis the figures decreases to 1.1 , 0.9 and $2.5 \mathrm{~km}$, respectively. Of all the sites where landslides interfere with the transportation network, $5.2 \%$ are characterised by slope failures that were classified as active in the geomorphological inventory map. At these sites damage caused by landslides is expected with a higher probabil- ity than in other sites, where landslides were not recognized as active.

Intersection between the geomorphological inventory map and the map of the built-up areas reveals that about $13.4 \%$ of the landslides shown in the inventory map intersect (i.e. interfere) with built-up areas (Table 6). This percentage is an average of one site every $1.4 \mathrm{~km}^{2}$, or 0.7 sites per $\mathrm{km}^{2}$. The figure decreases to one site every $1.1 \mathrm{~km}^{2}$ if large valley bottoms and intra-mountain basins are excluded from the analysis (i.e. 0.9 sites per $\mathrm{km}^{2}$ ). Of all these sites, $4.5 \%$ were affected by landslides that were classified as active in the geomorphological inventory map. These areas should be studied in greater detail in order to ascertain the actual landslide hazards and the associated risk.

It should be noted that the figures given above may be locally inaccurate. The analysis does not consider the possibility that a landslide can travel a long distance from the source area. The analysis may also be biased locally by the presence of tunnels below landslide shear planes, and of bridges or viaducts not affected by shallow landslides. In built-up areas remedial works may have been completed, reducing landslide hazards.

\section{Conclusions}

Determining the impact of landslides on the population, the transportation network, and the built-up areas in the Umbria 


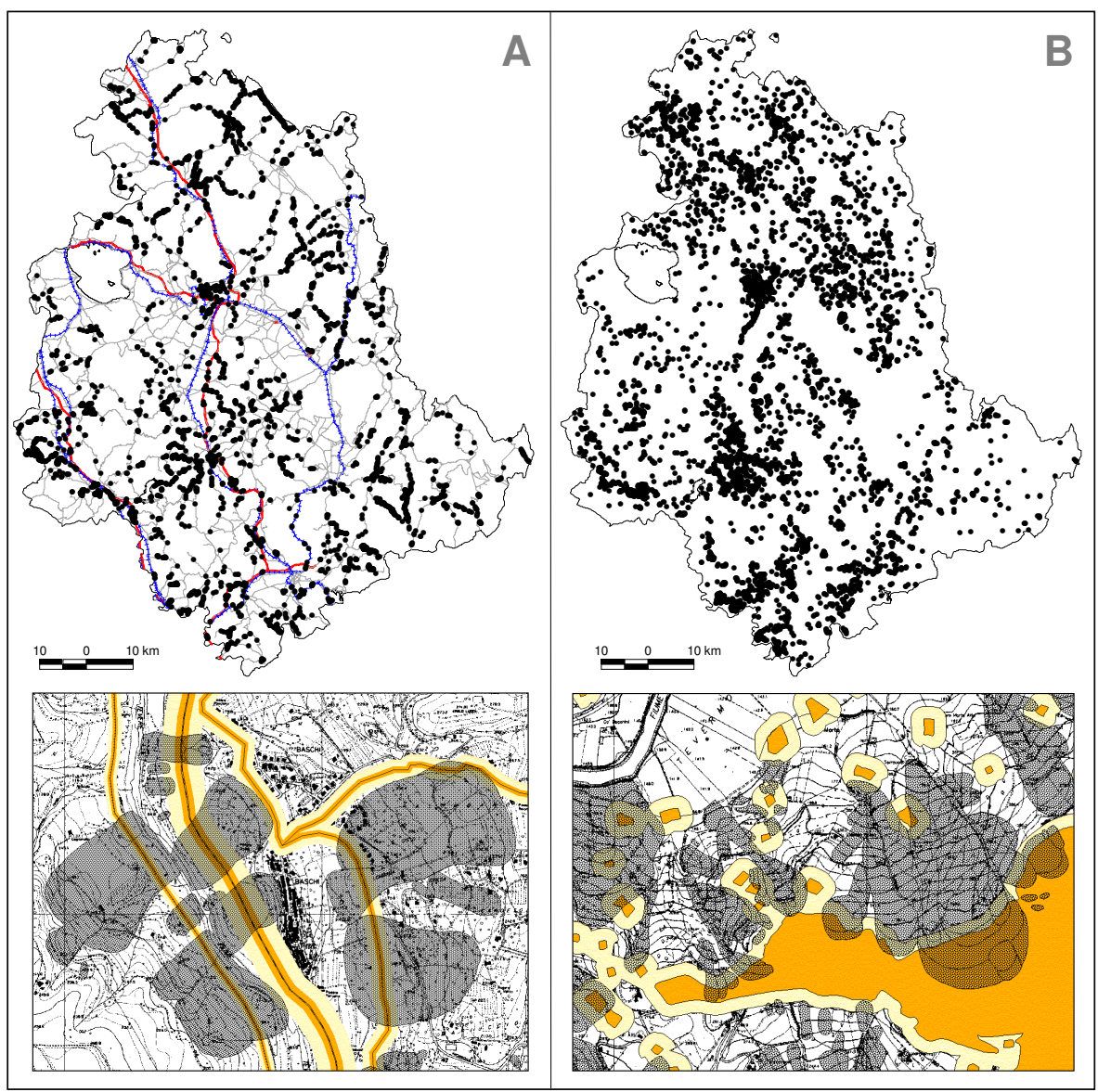

Fig. 14. Landslide impact in Umbria. (A) Location of 4,115 sites where landslides intersect the transportation network (see Fig. 6A). (B) Location of 6119 sites where landslides intersect built-up areas (see Fig. 6B). Lower maps are enlargements showing cartographic detail and performed geographical analysis. Legend: grey pattern, landslide; orange, extent of structure or infrastructure (buffer A); yellow, zone in the vicinity of structure or infrastructure (buffer B). For buffer size see Table 5.

Region is not an easy task. The extent, type and severity of the expected damage depend on the type and abundance of landslides, the type and density of elements at risk, and the local geomorphological setting. Completeness and reliability of the information on landslides and on the elements at risk must also be considered.

The type, quality and role of the sources of information on landslides and their damage vary. The historical archive of landslide events, albeit incomplete, allowed a minimum estimate of the average recurrence of damaging landslides in each Municipality in the Region, and an estimate of the exceedance probability of landslide occurrence for different time intervals. It also showed that the frequency of occurrence of landslides with human consequences in Umbria is much lower than the national figures, and lower than the frequency of landslides with other consequences (e.g. damage to built-up areas or the transportation network). This lower frequency depends on the type of landslides with consequences in the Umbria region.

The three landslide-event inventories provided information on the extent, abundance and pattern of landslides caused by a single trigger. The percentages of landslides triggered by rainfall events (in 1937-1941) and by rapid snow melting (in 1997) that interfered with the transportation network were very similar $(\sim 2.6 \%)$. The event inventories revealed a considerable spatial persistence of landslides. The majority ( $>75 \%$ ) of the triggered slope failures occurred inside or in the vicinity of pre-existing landslides, providing the rationale for using the geomorphological inventory map to evaluate where future landslides may occur. During prolongued rainfall similar to that in 1937-1941 and rapid snowfall melt similar to that in 1997, slope failures are likely to occur in or in the vicinities of pre-exsisting landslides. The event inventories also provided frequency-area and frequency-volume statistics of landslides, valuable information for preparing regional landslide scenarios and to ascertain landslide hazards and risk at the regional scale.

The geomorphological inventory map allowed establishing the extent of landslides in the Umbria region, and in each of its 92 Municipalities. The regional inventory allowed determining where landslides intersect with the built-up areas and the transportation network. At these sites landslide 
damage can be expected during prolonged or intense rainfall events, rapid snow melting events, or earthquakes. Analysis of the distribution of landslides in the Perugia Municipality allowed estimating the percentage of the population potentially subject to landslide risk.

Far from being an exhaustive assessment of landslide risk in Umbria, the study has demonstrated that the impact of landslides on the population, the transportation network, and the built-up areas can be determined qualitatively and quantitatively, where the proper information is available. To ascertain landslide risk in the Umbria Region, additional research is needed to fully exploit the data currently available on the past and present distributions of landslides, on the recurrence of landslide events, and on the type and extent of damage caused by slope failures.

Acknowledgements. The research was supported by CNR GNDCI and CNR IRPI funds, and by a specific grant of the Regione dell'Umbria and of the Tiber River Basin Authority. We are gratfull to Earl E. Brabb and to a second anonymous referee for the helpful comments. The paper is CNR GNDCI publication number 2633.

\section{References}

AA.VV.: Rapporto Conclusivo. Protocollo d'Intesa fra la Regione dell'Umbria, Direzione Politiche Territoriali Ambiente e Infrastrutture, ed il CNR-IRPI di Perugia per l'acquisizione di nuove informazioni sui fenomeni franosi nella regione dell'Umbria, la realizzazione di una nuova carta inventario dei movimenti franosi e dei siti colpiti da dissesto, l'individuazione e la perimetrazione delle aree a rischio da frana di particolare rilevanza, e l'aggiornamento delle stime sull'incidenza dei fenomeni di dissesto sul tessuto insediativo, infrastrutturale e produttivo regionale, 140 p., (in Italian), 2002.

Antonini, G., Ardizzone, F., Cardinali, M., Galli, M., Guzzetti, F., and Reichenbach, P.: Surface deposits and landslide inventory map of the area affected by the 1997 Umbria-Marche earthquakes. Bollettino Società Geologica Italiana, 121:2, Special Volume 1, 843-853, 2002.

Antonini, G., Cardinali, M., Guzzetti, F., Reichenbach, P., and Sorrentino, A.: Carta Inventario dei Fenomeni Franosi della Regione Marche ed aree limitrofe. CNR GNDCI Publication number 580, 2 sheets, map at 1:100 000 scale, (in Italian), 1993.

Cardinali, M., Ardizzone, F., Galli, M., Guzzetti, F., and Reichenbach, P.: Landslides triggered by rapid snow melting: the December 1996-January 1997 event in Central Italy. in: Mediterranean Storms, Proceedings Plinius Conference '99, Maratea, 14-16 October 1999, edited by Claps, P. and Siccardi, F., CNR GNDCI publication number 2012, 439-448, 2000.

Cardinali, M., Antonini, G., Reichenbach, P., and Guzzetti, F.: Photo-geological and landslide inventory map of the Upper Tiber River basin. CNR GNDCI publication number 2116, map at 1:100 000 scale, 2001.

Cardinali, M., Carrara, A., Guzzetti, F., and Reichenbach, P.: Landslide hazard map for the Upper Tiber River basin. CNR GNDCI publication number 2634, map at 1:100000 scale, 2002a.

Cardinali, M., Reichenbach, P., Guzzetti, F., Ardizzone, F., Antonini, G., Galli, M., Cacciano, M., Castellani, M., and Salvati, P.: A geomorphological approach to estimate landslide hazard and risk in urban and rural areas in Umbria, central Italy, Natural Hazards and Earth System Sciences, 2:1-2, 57-72, $2002 \mathrm{~b}$.

Cencetti, C. Conversini, P., Ribaldi, C., and Tacconi, P.: The landslide in Valderchianear near Gubbio, Umbria, Central Italy. in: Proceedings 8th International Congress International Association for Engineering Geology and the Environment, edited by Moore, D., and Hungr, O., Balkema, Rotterdam, 1469-1476, 1998.

Coe, J. A., Michael, J. A., Crovelli, R. A., and Savage, W. Z.: Preliminary map showing landslide densities, mean recurrence intervals, and exceedance probabilities as determined from historic records, Seattle, Washington, U.S., Geological Survey Open File Report 00-303, internet version, http://greenwood.cr.usgs.gov/ pub/open-file-reports/ofr-00-0303/, 2000.

Crovelli, R. A.: Probability models for estimation of number and costs of landslides, U.S. Geological Survey Open File Report 00-249, internet version, http://greenwood.cr.usgs.gov/pub/ open-file-reports/ofr-00-0249/, 2000.

Cruden, D. M. and Fell, R. (eds.): Landslide risk assessment. Proceedings International Workshop on Landslide Risk Assessment, Honolulu, 19-21 February 1997, Balkema, Rotterdam, 371, 1997.

Dussage-Peisser, C., Helmstetter, A., Grasso, J. R., Hantz, D., Desvarreux, P., Jeannin, M., and Giraud, A.: Probabilistic approach to rock fall hazard assessment: potential of historical data analysis. Natural Hazards and Earth System Sciences, 2, 15-26, 2002.

Einstein, H. H.: Special lecture: Landslide risk assessment procedure. Proceedings 5th International Symposium on Landslides, Lausanne, 2, 1075-1090, 1988.

Einstein, H. H.: Landslide Risk - Systematic approaches to assessment and management, in: Landslide Risk Assessment, Proceedings International Workshop on Landslide Risk Assessment, Honolulu, 19-21 February 1997, edited by Cruden, D.M. and Fell, R., Balkema, Rotterdam, 25-50, 1997.

Evans, S. G.: Fatal landslides and landslide risk in Canada. Proceedings International Workshop on Landslide Risk Assessment, Honolulu, 19-21 February 1997, Balkema, Rotterdam, 185-196, 1997.

Fell, R.: Landslide risk assessment and acceptable risk, Canadian Geotechnical Journal, 32:2, 261-272, 1994.

Fell, R., and Hartford, D.: Landslide risk management, in: Proceedings International Workshop on Landslide Risk Assessment Honolulu, 19-21 February 1997, edited by Cruden, D. and Fell, R., Balkema, Rotterdam, 51-109, 1997.

Felicioni, G., Martini, E., and Ribaldi, C.: Studio dei Centri Abitati Instabili in Umbria. Atlante regionale: CNR GNDCI publication number 979, Rubettino Publisher, 418, (in Italian), 1994.

Glade, T.: Establishing the frequency and magnitude of landslidetriggering rainstorm events in New Zealand, Environmental Geology, 35, 2-3, 160-174, 1998.

Guzzetti, F.: Landslide fatalities and evaluation of landslide risk in Italy, Engineering Geology, 58, 89-107, 2000.

Guzzetti, F. and Cardinali, M.: Carta Inventario dei Fenomeni Franosi della Regione dell'Umbria ed aree limitrofe, CNR GNDCI publication number 204, 2 sheets, map at 1:100000 scale, (in Italian), 1989.

Guzzetti, F., Cardinali, M., and Reichenbach, P.: The AVI Project: A bibliographical and archive inventory of landslides and floods in Italy, Environmental Management, 18, 623-633, 1994.

Guzzetti, F., Cardinali, M., and Reichenbach, P.: The influence of structural setting and lithology on landslide type and pattern, En- 
vironmental and Engineering Geoscience, 2:4, 531-555, 1996.

Guzzetti, F., Cardinali, M., Reichenbach, P., and Carrara, A.: Comparing landslide maps: A case study in the upper Tiber River Basin, central Italy, Environmental Management, 25:3, 247-363, 1999a.

Guzzetti, F., Carrara, A., Cardinali, M., and Reichenbach, P.: Landslide hazard evaluation: an aid to a sustainable development, Geomorphology, 31, 181-216, 1999b.

Guzzetti, F., Malamud, B. D., Turcotte, D. L., and Reichenbach, P.: Power-law correlations of landslide areas in Central Italy, Earth and Planetary Science Letters, 195, 169-183, 2002.

Hungr, O., Evans, S. G., ad Hazzard, J.: Magnitude and frequency of rock falls along the main transportation corridors of southwestern British Columbia, Canadian Geotechnical Journal, 36, 224-238, 1999.

Kong, W. K.: Risk assessment of slopes, Quarterly Journal of Engineering Geology and Hydrogeology, 35, 213-222, 2002.

Ibsen, M.L. and Brunsden, D.: The nature, use and problems of historical archives for the temporal occurrence of landslides, with specific reference to the south coast of Britain, Ventnor, Isle of Wight, Geomorphology, 15, 241-258, 1996.

Reichenbach, P., Cardinali, M., De Vita, L., and Guzzetti, F.: Regional hydrological thresholds for landslides and floods in the Tiber River basin (Central Italy), Environmental Geology, 35:23, 146-159, 1998.
Servizio Geologico d'Italia: Carta Geologica dell'Umbria, Map at 1:250 000 scale, (in Italian), 1980.

Servizio Idrografico: Precipitazioni medie mensili ed annue e numero di giorni piovosi per il trentennio 1921-1950, Bacini con foce al litorale tirrenico dal Fiora al Lago di Fondi, Ministero dei Lavori Pubblici. Publication N. 24:1, Rome, 234, (in Italian), 1955a.

Servizio Idrografico: Precipitazioni massime con durata da uno a cinque giorni consecutivi, Bacini con foce al litorale tirrenico dal Fiora al Lago di Fondi, Ministero dei Lavori Pubblici. Publication N. 25:1, Rome, 238, (in Italian), 1955b.

Servizio Idrografico: Annali Idrologici, Parte Prima, Bacini con foce al litorale tirrenico dal Fiora al Lago di Fondi. Various volumes from 1951 to 1960, Ministero dei Lavori Pubblici, Rome, (in Italian), 1955-1961.

Stark, C. P. and Hovius, N.: The characterization of landslide size distributions, Geophysics Research Letters, 28:6, 1091-1094, 2001.

Varnes, D. J.: Slope movements, type and processes, in: Landslide analysis and control, edited by Schuster, R. L. and Krizek, R. J., Transportation Research Board, National Academy of Sciences, Washington, D.C., Special report 176, 11-33, 1978.

Varnes, D. J. and IAEG Commission on Landslides and other Mass Movements on Slopes: Landslide hazard zonation: a review of principles and practice, UNESCO Press, Paris, 63, 1984. 